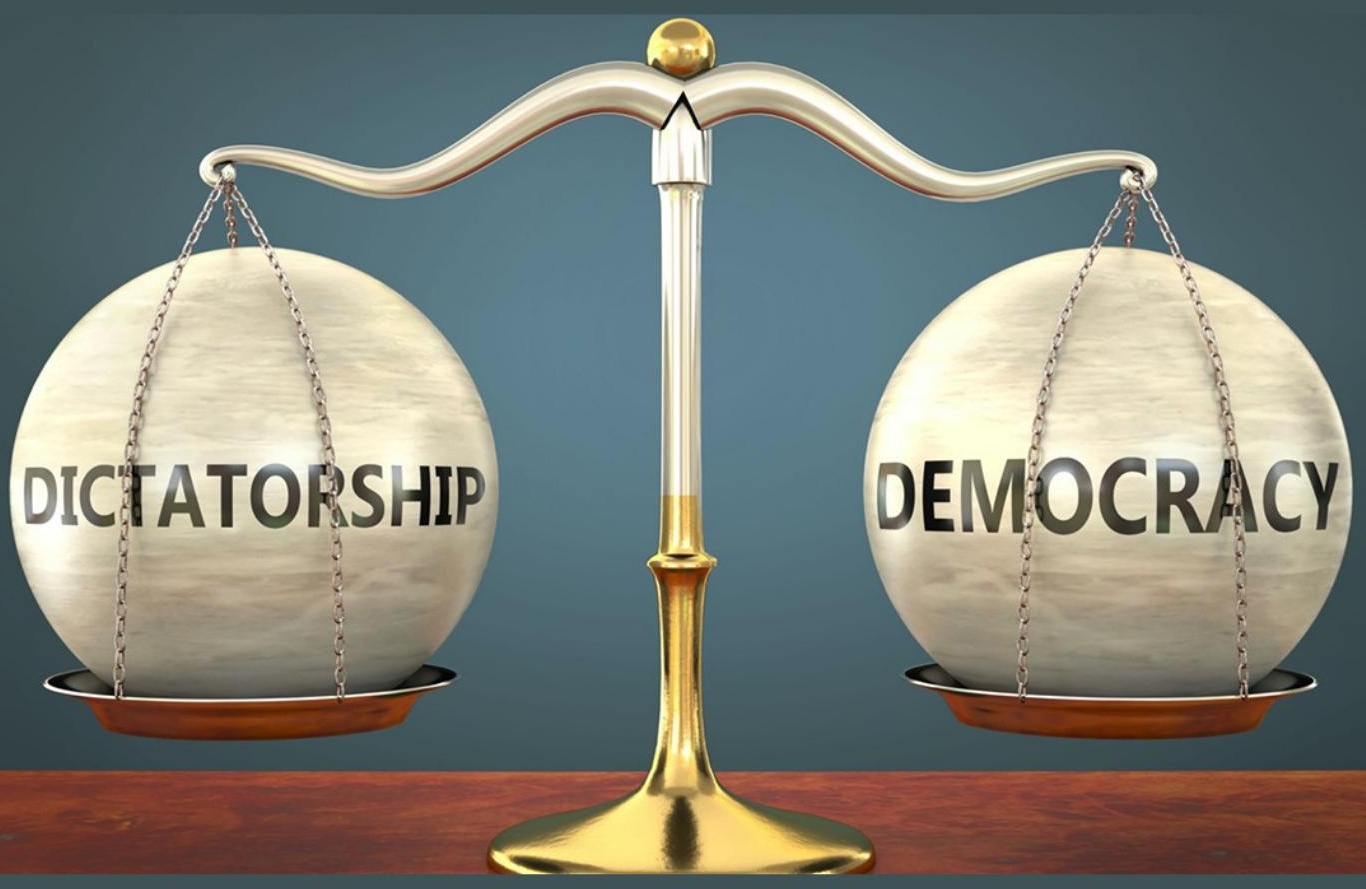

\title{
SYMPOSIUM ON \\ AUTHORITARIANISM \\ AND GOOD \\ GOVERNANCE
}

EDITED BY MUQTEDAR KHAN

Contributors:

Larry Diamond

Jessica Teets

Daniel Kinderman

Asma T. Uddin

Olga Gerasimenko

Fahmida Zaman

Sumeyra Yildirim

(tilt. 


\section{INTERNATIONAL INSTITUTE OF ISLAMIC THOUGHT}

\section{Symposium on Authoritarianism and Good Governance}

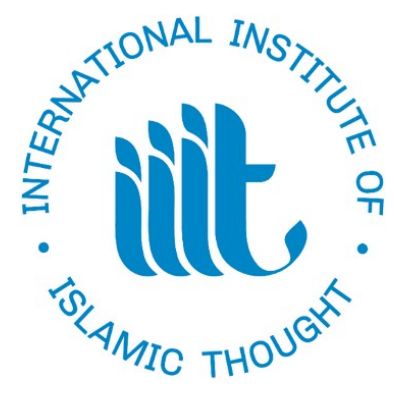


Copyright (C) 2021 by International Institute of Islamic Thought

All rights reserved. No part of this publication may be reproduced, stored or transmitted in any form or by any means, electronic, mechanical, photocopying, recording, scanning, or otherwise without written permission from the publisher. It is illegal to copy this book, post it to a website, or distribute it by any other means without permission.

First edition

Editing by Muqtedar Khan

Contributor: Larry Diamond

Contributor: Jessica Teets

Contributor: Daniel Kinderman

Contributor: Asma T. Uddin

Contributor: Olga Gerasimenko

Contributor: Fahmida Zaman

Contributor: Sumeyra Yildirim 


\section{Contents}

1 Introduction: Democracy Versus Authoritarianism 1

2 Regime Type and Effective Government: Is There (Still a... 10

3 Consultative Authoritarianism: The Key to Good Governance in China?

4 Authoritarian Capitalism and Its Impact on Business

5 Impact of Authoritarian Trends and Political Tribalism on Muslim Minorities in the US

6 The Weaponization of Digital Media in the Service of Authoritarianism

7 Annotated Bibliography $\quad 74$

8 Author Biographies $\quad 94$ 



\title{
Introduction: Democracy Versus Authoritarianism
}

\author{
Muqtedar Khan \\ Professor, Department of Political Science \& International Relations \\ University of Delaware
}

The past decade and a half have witnessed two clearly interconnected global trends, the decline of democracy and the rise of populist, majoritarian authoritarianism. According to the Democracy Index, published by the Economist Intelligence Unit (EIU), and the Freedom House Democracy Scores, democracy is not only in steady retreat but its quality in traditional democratic strongholds like the United States and Japan is also in decline. Both countries are now rated as flawed democracies. ${ }^{1}$

In my view there are three driving forces behind these trends: (1) Economic inequity; globalization has generated winners and losers, even in rich developed nations, causing discontent with the political order resulting in strife

\footnotetext{
1 The Democracy Index can be found here on the world wide web: https:// www.eiu.com/n/campaigns/democracy index-2020/ and the Freedom House ratings are here: $\underline{\text { https://freedomhouse.org/countries/nations-transit/scores. }}$.
} 
and protests, feeding the populist trends already in place. ${ }^{2}$ (2) The sudden increase in migrants and refugees who are engendering intolerance and antipluralist sentiments in nations that host a large number of international migrants, especially in Western countries; public opinion driven policies against immigrants are empowering right-wing hate groups, driving up hatecrimes and thus reducing the quality of democracy in some of these nations. ${ }^{3}$

(3) The rise of populism which is partly caused by the first two causes and partly by the escalation of right-wing conservative ideological movements together with racial and ethnic- nationalist reactions that have been festering for decades in places like Myanmar, India, Britain, France, Eastern Europe, and the United States. ${ }^{4}$

There are two types of authoritarian tendencies that are currently prevalent: (1) one trend is of existing authoritarian states becoming more authoritarian, for example, China, which based on its egregious treatment of Uyghurs and its harsh response to protests in Hong Kong, is being recognized as more authoritarian now than before. ${ }^{5}$ (2) The second trend is the rise of authoritarianism in countries considered democratic. For example, the US

\footnotetext{
2 Rodrik, Dani. "Populism and the economics of globalization." Journal of international business policy 1, no. 1 (2018): 12-33. Guriev, Sergei. "Economic drivers of populism." In AEA Papers and Proceedings, vol. 108, pp. 200-203. 2018. Rodrik, Dani. Why does globalization fuel populism? Economics, culture, and the rise of right-wing populism. No. w27526. National Bureau of Economic Research, 2020.

3 Zakaria, Fareed. "Populism on the March: Why the West is in Trouble." Foreign Affairs, 95 (2016): 9. Brubaker, Rogers. "Between nationalism and civilizationism: the European populist moment in comparative perspective." Ethnic and Racial Studies 40, no. 8 (2017): 1191-1226.

${ }^{4}$ Krastev, Ivan. "Eastern Europe's illiberal revolution: The long road to democratic decline." Foreign Affairs, 97 (2018): 49. Bang, Henrik, and David Marsh. "Populism: a major threat to democracy?" Policy Studies 39, no. 3 (2018): 352-363. Corbridge, Stuart, and John Harris. Reinventing India: Liberalization, Hindu nationalism and popular democracy. John Wiley \& Sons, 2013.

${ }^{5}$ Carpenter, Ted Galen, "Prepare for a More Authoritarian China", The National Interest, August 03, 2019. On the World Wide Web at: https://nationalinterest.org/feature/preparemore-authoritarian-china-70861
} 
and India. ${ }^{6}$ The first trend is lamentable because it reduces the quality of human rights for millions and increases their suffering while impeding or preventing democratization. The second trend is more worrisome because it reverses hard-earned victories for democracy and it also sets a bad example for states struggling between democracy and authoritarianism.

\section{Geopolitical Contest and the Competition of Governing Models}

The world is presently witnessing a geopolitical contest between the US and China for global hegemony. This is not just about who is more powerful but also whose model of governance is best. As such, the US-China contest is a de facto competition between democratic governance and authoritarianism. Developing and fragile nations, dependent for trade and security on these superpowers, are likely to emulate the model that appears to be more successful and less messy to implement. In addition to the rise of populism, the COVID-19 pandemic has added an additional dimension to this contest. The US, with over 450,000 deaths at the time of writing this essay, does appear to be managing this crisis terribly. ${ }^{7}$ There was a time when the US would have led the world against such a global pandemic, but today it cannot save its own population from a massacre. China, where the pandemic originated, in comparison, looks very much in control; unlike the rest of the world whose economies have shrunk in 2020, China, according to the IMF, is the only country to post positive growth to its GDP. ${ }^{8}$ This has prompted some to question the usefulness of democracy. In December 2020, I went on the biggest Hindi News platform in India to defend the democratic model over

\footnotetext{
${ }^{6}$ Vajpeyi, Ananya. "Minorities and Populism in Modi's India: The Mirror Effect." In Minorities and Populism-Critical Perspectives from South Asia and Europe, pp. 17- 28. Springer, Cham, 2020. Norris, Pippa, and Ronald Inglehart. Cultural backlash: Trump, Brexit, and authoritarian populism. Cambridge University Press, 2019.

7 Data provided by worldometer.com on January 30th, 2021. https:// www.worldometers.info/coronavirus/country/us/

${ }^{8}$ See IMF report: https://news.cgtn.com/news/2020-10-13/World-GDP-to-drop-4-4- in2020-IMF-UyNuoUIFlC/index.html
} 
the efficient but authoritarian model in China. ${ }^{9}$ Larry Diamond too touches upon this issue in his essay in this symposium reminding us that, in fact, the nations which have best handled the COVID-19 pandemic are democracies like Japan, Australia, New Zealand, and South Korea. ${ }^{10}$

Additionally, the images of treason and insurgency transmitted to the world on January 06, 2021, when an in-office President instigated a revolution against his own country sent the message that the US is spiraling down into chaos. It is no more a model of good governance or democracy, and in its current avatar certainly not worthy of emulation. I am confident that with the change in regime, the US will get back to its glory days, but at the moment it is losing soft power like a drunken sailor at a casino.

Political scientists who study development have long held that democracy was the key to both development and good governance. Democratic forms of government, in combination with open markets, have been deemed necessary for both economic as well as political development. Some of the indicators that measure democracy, such as inclusiveness and outreach, are also measures of good governance thus making democracy and good governance overlap. However, there are some significant exceptions. While some authoritarian states rank very low on both democracy and effectiveness in governance, like Yemen and Myanmar, there are some authoritarian states that are ranked very high when it comes to effective governance. Take the case of Singapore, which is ranked \#1 on effective governance and \#75 on democracy. ${ }^{11}$

There are nations like Norway, Sweden, Finland, and Switzerland which are both democratic as well as effective at governance. So, let us not

9 This interview can be heard here: https://www.aajtak.in/podcast/best-podcasts-inhindi/audio/if-india-really-has-too-much-democracy-1175535-2020-12-11

10 See Larry Diamond, "Regime Type and Effective Government: Is There (Still) a 'Democracy Advantage'?" in Muqtedar Khan (Ed.) Symposium on Authoritarianism and Good Governance (VA: IIIT, 2021).On the web at: https://iiit.org/en/regime-type- and-effective-government/

${ }^{11}$ See the EIU report cited in endnote $\# 1$ for the democracy rankings and see this report on the world wide web for efficiency ranking: https:// www.theglobaleconomy.com/rankings/wb government effectiveness/ 
assume that effective governance is the sole domain of authoritarian regimes. However, since 2006, we are witnessing a retreat of democracy and a rise in authoritarianism. The meteoric ascent of China, and its ability to now project power globally, is promoting its model of authoritarian governance with mercantilist capitalism as an alternative model to democracy and free government. ${ }^{12}$ Some scholars are already talking about the diffusion of the China model. ${ }^{13}$

There now appear to be two models of good governance, one based on democratic values and the other on effectiveness. The former emphasizes inclusivity, outreach, political freedoms, as well as democratic and human rights, whereas the latter center's growth, employment, and freedom from economic distress. In this symposium on authoritarianism and governance, we wish to shed light on some aspects of the two models. As the COVID19 pandemic rages, the contrast between the US and China is difficult to ignore. As populism and authoritarianism grow, will new challenges such as frequent pandemics and the environmental crisis privilege authoritarianism over democratic governance? Finally, the crisis of democracy in the US, so spectacularly highlighted by the Capitol Siege of January 06, 2021, makes the task of defending values-based governance more urgent than ever before.

\section{On the Essays in the Symposium}

We begin the conversation with a very optimistic and robust defense of the virtues as well as durability of democracy by Larry Diamond, who is one of the foremost scholars of democratization. In his essay, he explores the relationship between democracy and economic development along with democracy and good governance. He acknowledges that there is clearly a democracy deficit, but he also points out that overall, most of the best-

\footnotetext{
${ }^{12}$ Fukuyama, Francis. "Exporting the Chinese model." Project Syndicate 12 (2016). Halper, Stefan. The Beijing consensus: how China's authoritarian model will dominate the twenty-first century. ReadHowYouWant.com, 2010.

${ }^{13}$ Ambrosio, Thomas. "The rise of the 'China Model' and 'Beijing Consensus': evidence of authoritarian diffusion?.” Contemporary Politics 18, no. 4 (2012): 381-399.
} 
governed states are democracies and over time, a vast majority of states that have registered economic development are democratic. Cases like China and Singapore where both development and authoritarianism co-exist are exceptions and not the norm. He also argues that in spite of its success, the desirability of the China model is low. People in many authoritarian states aspire for democracy. One issue that Diamond does not discuss is the possible impact of US domestic politics on the image of democracy: Will the political divisions and increasingly bad governance in the US, highlighted by bad health care, structural racism, and domestic terrorism, take the shine off the democracy model? ${ }^{14}$ Jessica Teets, a very creative and meticulous scholar, looks at city governance and the prevalence and management of civil society institutions in China. She focuses on how civil society emerges and how it contributes to governance in authoritarian states. She advances the idea of 'consultative governance' to capture how China, recognizing the value of civil society groups to local governance, both permits their emergence and activities but also controls them. Essentially, the Chinese model has designed local sandboxes which confines the play of civil society institutions. As long as they provide policy-relevant and low-cost accurate information, they are allowed to operate, but if they challenge the authority of the government, they are reined in. Teets' research finds that civil society institutions in China are providing, at least at the level of city governance, many of the benefits of democracy without democratization, perhaps giving new meaning to the term smart cities. ${ }^{15}$ Teets' study of Chinese civil society institutions does raise the question about their nature. Are they extensions of the government itself - outsourcing information gathering and some policy implementation? Teets realizes that there are limits to the benefits

14 See Larry Diamond, "Regime Type and Effective Government: Is There (Still) a 'Democracy Advantage'?" in Muqtedar Khan (Ed.) Symposium on Authoritarianism and Good Governance (VA: IIIT, 2021). On the web at: https://iiit.org/en/regime-type-and-effective-government/

15 See Jessica Teets, "Consultative Authoritarianism: The Key to Good Governance in China?" in Muqtedar Khan (Ed.) Symposium on Authoritarianism and Good Governance (VA: IIIT, 2021). On the World Wide Web at: https://iiit.org/en/consultative-authoritarianism-the-key-to-good-governance-in- china/ 
this system provides with regards to quality of governance. Perhaps this arrangement, which allows for cooperation yet remains intolerant of conflict, is not consultative authoritarianism but rather a public-private partnership or even collusion in authoritarianism.

Daniel Kinderman, an interdisciplinary expert who studies the intersection of government and business examines the impact of authoritarianism on business. He looks at two Asian authoritarian states - China and Singapore - and two European democracies regressing towards authoritarianism-Hungary and Poland. His findings suggest that authoritarian states are able to facilitate business success and even when democracies tend towards authoritarianism, business success and innovation are not undermined. Clearly, his research indicates that business can easily find common ground with authoritarian and populist regimes. As a result, we could see the return of a neo-corporatist model replacing liberal democracies if the populist trends are not checked. ${ }^{16}$ Asma Uddin, a rapidly rising scholar and public intellectual on religious freedom issues, examines the concurrent effect of political tribalism and growing authoritarian tendencies infringing upon the rights of religious minorities, especially Muslims in the United States. ${ }^{17}$ She argues that the existential anxiety that is plaguing White Christian Americans is not only intensifying institutional and social discrimination against Muslims, but it is also minimizing the violation of Muslim religious rights. Even those mainstream institutions that fight for religious rights are not free from Islamophobia. In recent years, the partnership between an increasingly authoritarian President and his Evangelical Christian base succeeded simultaneously in raising the issue of religious discrimination while supporting and implementing a 'Muslim Ban.' Uddin's paper is an important reminder that under authoritarian leadership, even when religion is privileged, all religions

\footnotetext{
${ }^{16}$ See Daniel Kinderman, "Authoritarian Capitalism and its Impact on Business" in Muqtedar Khan (Ed.) Symposium on Authoritarianism and Good Governance (VA: IIIT, 2021). On the World Wide Web at: https://iiit.org/en/authoritarian-capitalism- and-its-impact-on-business/

${ }^{17}$ Uddin, Asma T. When Islam is Not a Religion. Simon and Schuster, 2019.
} 
are not treated equally. ${ }^{18}$

The final essay examines the role of technology in authoritarian governance. Social media, new digital platforms, and technologies have been greatly appreciated for their empowerment of ordinary citizens and democratizing public narratives. As such, they have been touted for reducing the imbalance of power between state and society, especially in authoritarian states. Olga Gerasimenko, in her essay, argues that the advantage that social media gave to civil society, as witnessed particularly during the Arab Spring revolutions of 2010-2011, has dissipated. States have now acquired enhanced technological ability, launched their own information portals as well as vehicles, and are using the same technology to control and manipulate public opinion in accordance with their policies. She shows how Russia and China have weaponized the digital media to manufacture consent both at home and abroad. I think her research also has implications on the technology fetish of trends such as "smart cities and smart governance." The same technology can lead to "smart surveillance and smart control."19

Zaman and Yildirim provide a very thorough and meticulously annotated bibliography of over fifty books and articles that address the topic of authoritarianism and governance. They have truly gone beyond what was expected in their 35-page, carefully vetted, and presented bibliography. ${ }^{20}$

\section{Conclusion}

${ }^{18}$ Asma Uddin, "Impact of Authoritarian Trends and Political Tribalism on American Muslims," in Muqtedar Khan (Ed.) Symposium on Authoritarianism and Good Governance (VA: IIIT, 2021). On the World Wide Web at: https://iiit.org/en/impact-of- authoritarian-trends-and-politicaltribalism-on-muslim-minorities-in-the-us/.

19 Olga Gerasimenko, "The Weaponization of Digital Media in the Service of Authoritarianism," in Muqtedar Khan (Ed.) Symposium on Authoritarianism and Good Governance (VA: IIIT, 2021). On the World Wide Web at: https://iiit.org/en/theweaponization-of-digital-media-in-the-service-of-authoritarianism/

${ }^{20}$ Fahmida Zaman and Sumeyra Yildirim, "Authoritarianism and Good Governance: An Annotated Bibliography," in Muqtedar Khan (Ed.) Symposium on Authoritarianism and Good Governance (VA: IIIT, 2021). On the World Wide Web at: 
The goal of this research program, Islam and Good Governance, ${ }^{21}$ inspired by my book and the theme of our first symposium, ${ }^{22}$ is to discuss and encourage the role of basic universal values in governance. In this second symposium, the essays cover issues that impact the centrality or marginality of values as democracy retreats and authoritarianism ascends. However, there are clear indications that values-based governance and democracy will eventually prevail. Diamond makes a strong case for the durability of democracy as a model of good governance and also highlights its attractiveness over authoritarianism. Teets asserts that the authoritarian model works best only when it shows a democratic tolerance for civil society. Kinderman suggests that the powerful business sector might be comfortable with authoritarianism and both Uddin and Gerasimenko warn of the dangers of authoritarianism to religious freedoms and democracy in general. We hope that this symposium, which underscores some of the contours of the discourse on democratic and authoritarian systems, will further advance the debates and reflections on the merits of democracy and the dangers of authoritarianism.

${ }^{21}$ Muqtedar Khan, Islam and Good Governance: A Political Philosophy of Ihsan (New York: PalgraveMacmillan, 2019).

${ }^{22}$ Muqtedar Khan (Ed.) Symposium on Islam and Good Governance (VA: IIIT, 2020), on the World Wide Web at: https://iiit.org/en/symposium-on-islam-and-good-governance/ 


\title{
Regime Type and Effective Government: Is There (Still) a 'Democracy Advantage?
}

\author{
Larry Diamond \\ Professor, Sociology and Political Science \\ Senior Fellow, Freeman Spogli Institute for International Studies \& The \\ Hoover Institution at Stanford University
}

Well before the onset of the COVID-19 pandemic, the meteoric rise of the People's Republic of China to the status of global superpower rekindled global debate over governance models. Since it began to open up its economy to private enterprise along with foreign trade and investment in 1979, under the relatively pragmatic Chinese leader, Deng Xiaoping, China has averaged annual GDP growth over nine percent, amounting to what the World Bank termed "the fastest sustained expansion by a major economy in history." 23 As a result, it has lifted hundreds of millions of people out of poverty in the space of just two generations. Within just a few decades, it has risen from lowincome status to become the world's second-largest economy (and the largest

23 Quoted in Congressional Research Service, "China's Economic Rise: History, Trends, Challenges, and Implications for the United States” Updated June 25, 2019, https://fas.org/sgp/crs/row/RL33534.pdf, p. 1 
as measured in purchasing power parity), as well as the global leader in "valueadded manufacturing, merchandise trade, and holder of foreign exchange reserves." 24 In the course of this transformation, China has gone from being a technologically backward country to global dominance in manufacturing, and a global challenger - if not leader - in such cutting-edge fields of technology as advanced digital telecommunications, artificial intelligence, and facial recognition. Although China's rapid progress in advanced technologies has come in no small measure due to theft and misappropriation of American and other Western intellectual property, ${ }^{25}$ the transformation of China's economy, physical infrastructure, and urban landscapes together with its dizzying pace of wealth creation had by the 2010s begun to awe the rest of the world, especially other developing countries.

China was the biggest and most recent country to achieve a developmental transformation under authoritarian rule, but it was to some extent following in the footsteps of other "East Asian Miracle" countries, particularly South Korea, Taiwan, and Singapore (also, to a lesser extent, the semi-democratic Malaysia). Moreover, recently other highly authoritarian countries, such as Rwanda, have claimed developmental success under non-democratic rule. All of this has generated renewed interest in the question: Does authoritarian rule or democracy offer a developmental advantage? In this essay, I will explore the relationship today between regime type and effective government and discuss whether people around the world have really been swayed by "the China model."

\section{Democracy, Governance, and Human Prosperity}

To answer the above question, we need to examine two types of relationships - between democracy and the quality of governance, and between democracy and economic development. Theoretically, scholars have long advanced strong reasons why democracy and the rule of law are strongly

\footnotetext{
24 Ibid.

${ }^{25}$ Diamond and Schell, chapter8, pp. 139-150.
} 
conducive to - if not always strictly necessary for- economic development. First, democratic institutions constrain the arbitrary power of rulers and thus constitute a check against predatory behavior, leading to secure property rights and economic growth. ${ }^{26}$ Second, democracies are more responsive to the public and thus better able to deliver public goods such as education and health care, thereby increasing the accumulation of human capital and enhancing economic growth. ${ }^{27}$ In addition, democracies provide mechanisms to moderate social conflicts and maintain political and economic stability. ${ }^{28}$ Finally, democracies are more likely to facilitate technological progress and encourage innovation. ${ }^{29}$ Open societies with freedom of speech are instrumental for generating and disseminating new ideas, which encourage innovation.

The features of governance that provide the enabling conditions for prosperity are closely related to democracy. The World Bank measures annually six different elements of the quality of governance based on the perceptions of thousands of informed experts and stakeholders in the private

\footnotetext{
${ }^{26}$ Douglass North, (1990). Institutions, Institutional Change and Economic Performance. Cambridge: Cambridge University Press; Douglass North and Barry Weingast, (1989). "Constitutions and Commitment: The Institutions Governing Public Choice in Seventeenth Century England," Journal of Economic History 44(4): 803-832; Mancur Olson, (1993). "Democracy, Dictatorship and Development," American Political Science Review 87(3): 567-576.

${ }^{27}$ Bruce Bueno de Mesquita, Alastair Smith, Randolph Siverson and James Morrow, (2003). The Logic of Political Survival. Cambridge, MA: MIT Press; Matthew Baum and David Lake, (2003). "The Political Economy of Growth: Democracy and Human Capital," American Journal of Political Science47(2): 333-347.

28 Dani Rodrik, (2000)."Participatory Politics, Social Cooperation, and Economic Stability," American Economic Review 90(2): 140-144

${ }^{29}$ Morton Halperin, Joe Siegle, Michael Weinstein, (2005). The Democracy Advantage: How Democracies Promote Prosperity and Peace. New York: Routledge; Helen Milner,(2006), "The Digital Divide: The Role of Political Institutions in Technology Diffusion," ComparativePolitical Studies 36(2): 176-199
} 
sector, NGOs, and public sector agencies. ${ }^{30}$ Three of these measures capture particularly well the conditions for sustained prosperity:

- Rule of Law: "the quality of contract enforcement, property rights, the police, and the courts, as well as the likelihood of crime and violence."

- Control of Corruption: "the extent to which public power is exercised for private gain, including both petty and grand forms of corruption, as well as 'capture' of the state by elites and private interests."

- Regulatory Quality: "the ability of the government to formulate and implement sound policies and regulations that permit and promote private sector development." 31

Empirically, each of these three measures is very strongly related to democracy (and to the other two governance measures). The overall correlation (which can range from -1 to +1 ) between the rule of law and the extent of democracy is about 0.75 (for the Varieties of Democracy (V-Dem) measure of Liberal Democracy ${ }^{32}$, or 0.72 for the Freedom House scale of political rights and civil liberties ${ }^{33}$ ). The positive correlations between democracy and regulatory quality are almost identical to rule of law $(0.75$ and 0.73$)$. The correlations with control of corruption are slightly lower (0.67 and 0.62$)$, but the two democracy scales correlate higher with Transparency International's measure of corruption control ( 0.75 and 0.70$)$. All of these correlations are

\footnotetext{
${ }^{30}$ Daniel Kaufmann, Aart Kraay, and Massimo Mastruzzi, "Governance Matters VIII:Aggregate and Individual Governance Indicators, 1996-2008," World Bank Policy Research Working Paper No. 4978, June 2009, https://papers.ssrn.com/sol3/papers.cfm?abstract id=1424591, p. 4.

31 Ibid, p. 6.

32 “Autocratization Surges-Resistance Grows," V-Dem 2020 Democracy Report,pp. 3032 . https://www.v-dem.net/media/filer public/de/39/de39af54-0bc5-4421-89aefb20dcc53dba/democracy report.pdf

${ }^{33}$ Freedom House, "Freedom in the World2020: A Leaderless Struggle," $\quad$ https://freedomhouse.org/sites/default/files/202002/FIW 2020 REPORT BOOKLET Final.pdf.
} 
highly statistically significant. Moreover, these associations are highly robust across different regions of the world. While they are weaker within Asia (generally between 0.3 and 0.5 ) they are still mostly statistically significant, and within some regions, they are especially strong (over 0.80 in Central and Eastern Europe). In most regions of the world (save the Middle East), the quality of governance is strongly positively related to the degree of democracy. We get a similar perspective if we examine the Heritage Foundation's 2020 Index of Economic Freedom, ${ }^{34}$ an aggregate score evaluating rule of law, government size, regulatory efficiency, and openness of markets. Of the 35 countries rated free or mostly free, 29 are democracies and two (Malaysia and Armenia) have had pluralistic and competitive political systems that have been approaching democracy. The four authoritarian regimes are mainly familiar among the authoritarian "success stories": Singapore, UAE, Qatar, and Rwanda. By contrast, most of the 19 worst economically repressed countries are politically authoritarian regimes, such as Iran, Zimbabwe, and Venezuela. Over 80 percent of the economically freest countries are democracies, and nearly 80 percent of the least economically free countries are authoritarian regimes. The world's most liberal democracies in political terms also generally have the freest economies.

\section{Democracy and Economic Development}

China benefited dramatically from its opening up to the world economy and market forces, but it was (especially in the early years) able to achieve such dramatic economic growth in part because of the size of its market and the huge reserve of low-wage labor it could mobilize for manufacturing. In general, other developing countries could not deploy these advantages of scale and market power, which enabled China to attract massive foreign investment despite high levels of corruption and a weak rule of law.

Over the decades, the econometric literature has generated somewhat conflicting evidence on the relationship between economic development

\footnotetext{
${ }^{34}$ https://www.heritage.org/index/ranking?version=468.
} 
and democracy. More recent studies, however, have tended to affirm "the democracy advantage." An analysis of about 150 countries over the period 1960 to 2000 found that percentage point annual increase in economic growth. ${ }^{35}$ Similarly, an analysis of up to 166 countries during the 1960-2003 period showed that democratic transitions are associated with an increase of one percentage point in annual GDP per capita growth, and the effect is relatively larger in "partial democratizations" 36 and in the medium and long run. ${ }^{37}$ Most recently (and exhaustively), Daron Acemoglu and his colleagues, drawing on a sample of 175 countries from 1960 to 2010, consistently find that democratization increases GDP per capita by approximately 20 percent in the long run (more than 25 years). ${ }^{38}$ In other words, the GDP per capita of the typical authoritarian regime would be 20 percent higher today had it democratized 25 years ago. Furthermore, the effect of democratic institutions is cumulative in the sense that democratic stock-a country's democracy history - is found to be robustly associated with economic growth rates. ${ }^{39}$

Contemporary patterns suggest the strong relationship between economic development level and democracy continues to hold. As measured by per capita income, only four of the 25 richest countries - Singapore, Qatar, Kuwait, and UAE - are non- democracies. In fact, only one of those, Singapore, became wealthy by its own entrepreneurial initiative, as opposed to the natural resource windfall of oil. With every step down the ladder of

35 Torsten Persson and Guido Tabellini, (2006). "Democracy and Development: The Devil in the Details," American EconomicReview 96(2): 319-324

36 "Full" democratization is coded when both the Polity indicator is greater than +7 and the FH status characterization is "free". All remaining democratization countries are coded as "partial".

${ }^{37}$ EliasPapaioannou and GregoriosSiourounis, (2008). "Democratization and Growth," The Economic Journal118 (October):1520-1551

${ }^{38}$ Daron Acemoglu,Suresh Naidu, PascualRestrepo and James A. Robinson, "Democracy Does Cause Growth," Journal of Political Economy127 (2019): 47-100.

39 John Gerring,Philip Bond, WilliamBarndt and CarolaMoreno, (2005). "Democracy and Economic Growth: A Historical Perspective," World Politics 57(3) : 323-364; Torsten Persson and Guido Tabellini, (2009). "Democratic Capital: The Nexus of Political and Economic Change," American Economic Journal: Macroeconomics 1(2), 88-126 
wealth, the percentage of authoritarian regimes rises. While authoritarian regimes represent only one-fifth of the 50 richest countries, they account for more than three-quarters of the 57 poorest countries.

A better way to measure development than per capita income (which tells us nothing about distribution) is the UNDP's Human Development Index (HDI), which controls somewhat for income inequality by averaging three measures: gross national income per capita (in purchasing power parity dollars); health, as measured by years of life expectancy; and education (an average of the current expected years of schooling for children at school-entry age and the mean actual years of schooling of the adult population).$^{40}$ Because the HDI controls for inequality and tempers the artificial, distorting effect of oil wealth, it is more highly correlated with democracy (about 0.70 ). ${ }^{41}$ This means nearly half of the variation $(\mathrm{R} 2=0.49)$ in the 2019 HDI scores can be explained simply by the level of democracy in a country (as measured by the annual Democracy Index of The Economist ${ }^{42}$ ). Among the top 25 states in human development, only Singapore is not a democracy. The next 25 include several oil-rich states (along with Russia and Belarus), but the step pattern then strikingly continues: with each step down the ladder of human development, there are fewer and fewer democracies. Among the bottom 38 countries in Human Development, 80 percent are authoritarian regimes.

The Economist's Democracy Index summarizes democracy scores into four categories: full democracies, flawed democracies, hybrid regimes, and authoritarian regimes. The latter two non-democratic regime types have significantly lower average HDI scores (a little over 0.610 ) than do the democracies. Even the flawed democracies score much higher $(0.786$ on average) and the full (liberal) democracies perform by far the best (0.902). By any measure, and over any time period, democracies are more

\footnotetext{
40 https://ourworldindata.org/human-development-index\#.

${ }^{41}$ The correlation for 2018 betweenHDI scores and the FreedomHouse scale is about 60.

42 https://www.eiu.com/topic/democracy-index. This correlation is computed by excluding the five oil-rich Gulf states (Bahrain, Kuwait, Qatar, Saudi Arabia, and UAE), whose artificial oil wealth relative to population distorts the results. If these are excluded, the R2 drops to .42 , which is still substantial.
} 
prosperous than authoritarian regimes - and when one looks at "real" human development, rather than just the average money income, the advantage increases. If we look at HDI scores over the past decade (2010-2019) according to the type of regime that has prevailed over the entire decade, the same pattern holds. The countries that have been continuously liberal democracies over the decade — with strong protections for rule of law, private property, and control of corruption - have achieved and maintained the highest levels of human development ( 0.84 on average). Electoral democracies have performed better than hybrid regimes or continuous autocracies, but the difference is much smaller (0.68 vs. 0.62$)$.

\section{The Impact of the COVID-19 Pandemic}

When the COVID-19 pandemic began to sweep across the globe in the Spring of 2020, there was already a strong pro-authoritarian narrative gathering momentum, as it had done in the 1960s and 70s. This was due in part due to China's phenomenally rapid rise and in part to China's own trumpeting of its model of governance as superior to that of the Western democracies.

Several other factors also contributed to what seemed to be the diminishing luster of democracy around the world. For one thing, democracy has been in a protracted recession that has seen levels of freedom and democracy weaken steadily for fourteen years. ${ }^{43}$ In the early years of this recession, the deterioration was modest and somewhat debatable, but in recent years more and more democracies have been degraded or overcome by authoritarian populist demagogues and other authoritarian challengers, to the point where the trend is now widely acknowledged and increasingly the subject of alarming annual reports. ${ }^{44}$ Even more damaging to the reputation of democracy has been the diminishing efficacy and declining quality of

\footnotetext{
${ }^{43}$ Larry Diamond, Ill Winds: Saving Democracy from Russian Rage, Chinese Ambition, and American Complacency (New York: Penguin Books, 2018).

${ }^{44}$ See the recent annual reports of Freedom House, V-Dem, and the Economist Democracy Index.
} 
many of the world's richest and most powerful democracies, especially the United States under the chaotic and illiberal presidency of Donald Trump. Consequently, more and more people have been asking if democracy is really the best, most effective system of governance.

Then came the COVID-19 pandemic. Although the virus emerged in Wuhan, China, and reached epidemic and then pandemic proportions because of the lack of transparency and press freedom in China-which enabled local Chinese officials to cover it up and infected people to leave Wuhan and even China itself - China did get relatively firm control of the virus with drastic measures of lockdown and surveillance after the initially disastrous outbreak. The world's democracies, by contrast, largely failed to do so. Even allowing for the likely considerable under-reporting of COVID-19 cases and fatalities in less developed countries and in countries under authoritarian rule, the data still tell a stark story. Almost all of the countries hardest hit by COVID-19, particularly in COVID deathsper100,000 inhabitants, have been democracies. Most of these have been in Europe (led by Belgium, Italy, Spain, UK, and France) and in Latin America (Peru, Mexico, Argentina, and Brazil), but the United States has consistently been among the top 10-15 countries in terms of fatality rate, and it leads all other countries by a wide margin in the raw numbers of confirmed cases and total deaths. ${ }^{45}$ Yet democracies have also been among the best performers in containing the pandemic, most of all Taiwan but also South Korea, Australia, New Zealand, and Japan. These countries benefited not only from geography but from effective governments with strong public health systems that learned lessons from the SARS crisis in 2002-3. These Asian- Pacific countries, and others like Germany, demonstrated that it is possible to have a competent government managing a pandemic without sacrificing freedom: "The successful governments responded early and vigilantly, with widespread testing and contact tracing, and they communicated with their publics in a transparent, coordinated

\footnotetext{
${ }^{45}$ Johns Hopkins Coronavirus Resource Center, https://coronavirus.jhu.edu/data/mortality.
} 
manner that put health professionals at the forefront." 46 There was nothing about the required response that gave authoritarian regimes an intrinsic advantage; as a matter of fact, the transparency of democracies conferred certain benefits. However, the stubborn advance of the pandemic in many of the world's wealthiest democracies has further damaged their global statureand that of democracy, too.

\section{Do People Want the China Model?}

Despite the seeming spectacular success of the "China model," global public opinion has recently shifted dramatically away from sympathy toward China. A summer 2020 survey of 14 advanced industrial democracies (in Europe, the U.S., Canada, Australia, Japan, and South Korea) found that sizable majorities in each country (ranging from 62 to $86 \%$ ) had an unfavorable view of China. In most of these countries, disapproving views are at their highest level ever recorded in the survey, even though nearly all the countries still see China as the world's leading economic power. This rising hostility owes in part to negative assessments of how China has handled the virus, with an average of $61 \%$ across the 14 countries saying China has done a bad job of dealing with COVID-19. Further, it is a reaction against China's increasingly aggressive efforts to dominate global politics and trade through bullying, intimidation, propaganda, censorship, corruption, and other "sharp power" tactics. ${ }^{47}$ As a result, a median of 78 percent in the 14 countries say they have no confidence

46 Larry Diamond, "Democracy vs. the Pandemic," Foreign Affairs, June 13, 2020, https://www.foreignaffairs.com/articles/world/2020-06-13/democracy-versuspandemic.

${ }^{47}$ Diamond and Schell, China's Influence and American Interests; Diamond, Ill Winds, ch. 7, pp. 127-146; International Forum for Democratic Studies, National Endowment for Democracy, "Sharp Power: Rising Authoritarian Influence," December 5, 2017, https://www.ned.org/sharp-power-rising-authoritarian-influence-forum-report/; Christopher Walker, "What is 'Sharp Power'?” Journal of Democracy 29 (July 2018): 9-23. 
"in Chinese President Xi Jinping to do the right thing in world affairs."48 The Pew survey found even lower confidence in US President Donald Trump along with more negative evaluations of how the US has handled the virus (as compared to China). However, the damage that this sorry record of the US has done to global opinions about regime alternatives is mitigated by the fact that, in contrast to China, a democracy like the US can — and, in fact, recently did - replace a bad leader, and (as noted above) many democracies have done a better job of managing the pandemic.

Hence, China's rise and democracy's disappointments have so far done little to dampen the overall global enthusiasm for democracy as a form of government. Recent surveys (albeit preceding the COVID pandemic) show strong continuing support for such democratic principles as honest, competitive elections to choose leaders, an impartial judicial system, and freedom of expression. In fact, between 2015 and 2019 (the most recent Pew survey), support for free elections increased in more countries (eight) than it declined(five). ${ }^{49}$

Even in the poorest region of the world, sub-Saharan Africa, the attachment to democracy remains robust. In its latest (2019-20) round of surveys (albeit only so far for 18 of the 34 countries in the project), the Afrobarometer found: "Across 18 countries, more than two-thirds (68 percent) of respondents expressed a preference for democracy over any other political system, a preference that has remained fairly steady since 2011. Even larger proportions reject presidential dictatorship ( 81 percent), one-party rule (76

${ }^{48}$ Laura Silver, Kat Devlin, and Christine Huang, "Unfavorable Views of China Reach Historic Highs in Many Countries," Pew Research Center, October 6, 2020, https://www.pewresearch.org/global/2020/10/06/unfavorable-views-of-chinareachhistoric-highs-in-many-countries/.

49 Richard Wike and Shannon Schumacher, "Democratic Rights Popular Globally But Commitment to Them Not Always Strong," Pew Research Center, February 27, 2020, https://www.pewresearch.org/global/2020/02/27/attitudes-toward-democratic-rightsandinstitutions/. 
percent), and military rule (73 percent). ${ }^{, 50}$ Globally, there has been erosion in support for democracy (particularly in Latin America), but this appears to be more in response to performance failures that citizens perceive in their own democracies. In every region of the world that has been surveyed, democracy remains (on average) the favored model of government. ${ }^{51}$ Indeed, survey results from authoritarian regimes show that democracy "remains the regime for which people long when they live under the heels of rulers who rob them of their rights and freedoms." 52

In sum, despite China's stunning rise to global power and its muscular efforts to promote its model of authoritarian governance, democracy - though blemished and humbled-remains the preferred form of government in the world, and the best form of government not only for protecting rights but for delivering sustained and broadly distributed prosperity. Yet, ordinary people's faith in democracy is stubborn but not blind. If the United States and other democracies do not ultimately vanquish the virus and demonstrate anew the capacity for effective governance, public support for democracy will eventually experience much greater and more disastrous erosion.

\footnotetext{
${ }^{50}$ Carolyn Logan and E. Gyimah-Boadi, "African citizens expect more from their lives - and their governments, Afrobarometer surveys find," Washington Post, October 23, 2020, https://www.washingtonpost.com/politics/2020/10/23/african-citizens-expectmoretheir-lives-their-governments-afrobarometer-surveys-find/.

${ }^{51}$ Yun-han Chu, Kai-Ping Huang, Marta Lagos, and Robert Mattes, “A Lost Decade for ThirdWave Democracies?” Journal of Democracy 31 (April 2020): 166-181.

52 Ibid, pp. 175-76.
} 


\title{
Consultative Authoritarianism: The Key to Good Governance in China?
}

\author{
Jessica C. Teets \\ Associate Professor |Political Science Department | Middlebury College \\ Associate Editor of the Journal of Chinese Political Science
}

In 2014, I published a book entitled Civil Society under Authoritarianism, in which I addressed the puzzle of why the strong state in China did not repress emerging civil society, but instead allowed these groups to form and, in some policy areas, even actively supported their development and projects. I argued that over time government officials learned that these groups could improve local governance, and in response, they tried to balance between gaining these benefits while avoiding the dangers of potential citizen mobilization and protest. I used the concept of "consultative authoritarianism" to describe this specific combination of improving governance through consultation with civil society while developing a supervision structure that controlled these organizations. I emphasized the authoritarian nature of this system to warn democratization scholars that this emerging civil society should not be understood as a precursor to a process of democratization. In much the same way that other scholars were demonstrating that authoritarian regimes could repurpose democratic institutions like elections and parliaments to address 
elite conflict, ${ }^{53}$ I found that civil society could develop in a non-democratic setting. In fact, civil society contributed to more responsive governance by ameliorating welfare and other policy problems, and helped create more durable regimes. Thus, rather than being a challenger, it could also be a partner to authoritarian governments.

The logic underlying why a strong authoritarian government would allow civil society activity is rooted in the information problems faced by such regimes. Unlike democracies, authoritarian regimes do not have good sources of unbiased information. These regimes usually strictly control media, and elites often do not have incentives to share information on preferences with leaders. ${ }^{54}$ In democracies, elites can gain political power when they publicly defect from leaders or expose corruption unlike elites in authoritarian regimes; thus, rulers suffer from a lack of knowledge about preferences of citizens and other elites. In addition to the problems this dearth of information causes for elite cohesion, ${ }^{55}$ it also leads to obstacles for good governance in the form of principle-agent issues between central and local leaders. If central government leaders do not know how policies are performing in far-flung locales or whether local state agents are following regulations or engaging in corruption, this generates insurmountable hurdles for formulating good policies and having responsive government. One way that leaders in China responded to this paucity of knowledge was to empower civil society organizations (CSOs) to create transparency around local problems. ${ }^{56}$ This built low-cost flows of reliable information about policy and local agent performance that the state could use to improve governance and strengthen authoritarian resilience.

${ }^{53}$ Gandhi, Jennifer and Ellen Lust-Okar, 2009. Elections under Authoritarianism, Annual Review of Political Science 12: 403-422.

${ }^{54}$ Brownlee, J. 2007. Authoritarianism in an Age of Democratization. Cambridge and New York: Cambridge University Press.

${ }^{55}$ Svolik, MW. 2012 The Politics of Authoritarian Rule. Cambridge and New York: Cambridge University Press.

${ }^{56}$ Yang, Fan, Zhihan Zhang and Shizong Wang, 2020. Enlisting citizens: forging the effectiveness of policy implementation in local China, Journal of Chinese Governance. 
The time period encompassed by my research was from the late-1990s to 2013, spanning the administrations of both Jiang Zemin (1993-2003) and $\mathrm{Hu}$ Jintao (2003-2013). These two administrations supervised civil society using a 'dual registration' system, where groups needed a professional supervisory unit like a government agency and to register with the Ministry of Civil Affairs (MCA). This system prioritized control over groups by using risk-sharing between supervisory agencies and CSOs, and by requiring that organizations registering with MCA had a certain amount of funding. This high bar for registration resulted in a growing area of "grey civil society" where many groups operated quite openly but without formal registration. ${ }^{57}$ In recognition of the ineffectiveness of this system, Hu Jintao allowed some local leaders to experiment with permitting CSOs to register directly with MCA and no longer required a supervisory agency. As it evolved throughout the 2000s, this supervision model resulted in the consultative authoritarianism model I described above, creating channels whereby citizens were able to improve governance even under the conditions of authoritarianism.

However, in 2013, political power shifted from Hu Jintao to the new President, Xi Jinping, who began to change civil society governance. In 2016, two laws regulating CSOs were passed - the Charity Law (for domestic CSOs) and FNGO law (for foreign NGOs). The FNGO law required that overseas NGOs would come under the authority of the Ministry of Public Security and be required to have a supervisory agency, similar to the former requirement for domestic CSOs. In short, moving overseas NGOs under the Public SecurityBureau demonstrated that the Chinese Communist Party viewed their work as falling within the purview of law and order and social stability, rather than of civil affairs. ${ }^{58}$ In balance, this law increased state control over foreign NGOs in return for a more regular legal status, such as having Chinese bank accounts and a tax-deductible standing. In contradistinction,

\footnotetext{
${ }^{57}$ Hildebrandt, Timothy.2011. The political economy of social organization registration in China. The China Quarterly, 208, pp.970-989.

58 Teets, Jessica and Hsu, C., 2016. Is China's new overseas NGO management law sounding the death knell for civil society? Maybe not. The Asia-Pacific Journal, 14(4).
} 
the domestic charity law codified the existing practice of many provinces to ease registration by eliminating the need for a supervisory agency and only requiring direct registration with $\mathrm{MCA}$; it also encouraged private donations by changing tax laws and offered more government funding through grants and contracting. 59

Scholars reacted to these changes by trying to determine if Xi Jinping was attempting to standardize different provincial practices or simply suppress this nascent civil society. For example, Fu and Distelhorst ${ }^{60}$ find increasing repression under Xi Jinping. For example, Xu Zhiyong's case is illustrative of this repressive trend. When his CSO Gongmeng (New Constitution Initiative), was forced to close, he believed that space no longer existed for CSOs and decided to "organize without organization" by forming an online community called the New Citizens Movement (NCM). ${ }^{61} \mathrm{He}$ is currently being held for trial again for critiquing Xi's handling of COVID-19. ${ }^{62} \mathrm{As}$ Béja ${ }^{63}$ argues, the Party has adopted a two-pronged approach: "On one hand, it has encouraged the development of those that provide various kinds of services, and, on the other hand, it has attempted to eradicate grassroots advocacy organizations. Even the term 'civil society' (gongmin shehui) has become taboo." These changes raise the question of whether China still practices the consultative authoritarianism model, and if not, the implications of this shift.

\section{Do These Changes Challenge the Concept of Consultative}

\footnotetext{
${ }^{59}$ Sun, T. 2019. Deliberate Differentiation by the Chinese State: Outsourcing Responsibility for Governance. The China Quarterly, 240, 880-905.

${ }^{60} \mathrm{Fu}$, Diana and Distelhorst, G. 2018. Grassroots participation and repression under Hu Jintao and Xi Jinping. The China Journal, 79(1), 100-122.

${ }^{61}$ Pils, Eva. 2017. From Independent Lawyer Groups to Civic Opposition: The Case of China'sNew Citizens Movement.Asian-Pacific Law \& PolicyJournal 19 (1): 110-52.

62 South China MorningPost. 6 February 2020.“Chinese scholar blamesXi Jinping, Communist Party for not controlling coronavirus outbreak."

${ }^{63}$ Béja, J. 2019. Xi Jinping's China: On the Road to Neo-totalitarianism. Social Research: An International Quarterly 86(1), 203-230.
} 


\section{Authoritarianism?}

Most of the foreign NGOs active in China have been able to register under the new regulations or file documentation for "temporary activities," which does not require a professional supervisory agency, making the process less onerous. The Overseas NGO Law went into effect on January 1, 2017, and as of November 2018, overseas NGOs had registered 427 representative offices and filed 1,179 temporary activities. ${ }^{64}$ Foreign NGOs have noted difficulties in gaining quick approval for certain projects with local partners along with increased inspection of activities through project approvals and the annual work report. This annual report must include financial statements, auditing reports, and information on donations, as well as any changes in staffing or organization. Thus, despite these modifications that have made operating in China more cumbersome, foreign NGOs have mostly continued their work.

Domestic charities have experienced a dramatic shift in funding sources since the law went into effect, shifting from mostly international grant funding to domestic fundraising and government grants: "Ten years ago, many rights-based CSOs I spoke with had $80-90 \%$ of their funding coming from international sources. Now, some of these CSOs have $80-90 \%$ coming from Chinese sources. The Chinese CSOs I interviewed had tapped into many of these local sources - local philanthropy, government fees-forservice, corporate partnerships, social enterprise, and crowdfunding". 65 As Dong and $\mathrm{Lu}^{66}$ find, many organizations now are primarily funded by

government contracts. This shift in funding combined with heightened political sensitivities to result in the closure of many smaller grassroots groups and a few high-profile closures and arrests. The combined effects reinforce the centralized leadership of the Party—what Kang Xiaoguang calls

\footnotetext{
${ }^{64}$ Shieh, Shawn and Mark Sidel. 2019. Nonprofit Law in China. Accessed December 18, 2020 : https://www.cof.org/content/nonprofit-law-china

${ }^{65}$ Shieh, Shawn. 2020. Is China the future for hybrid CSO funding models? Accessed June 2020: https://www.openglobalrights.org/is-china-the-future-for-hybrid-cso-funding- models/

${ }^{66}$ Dong Q and Lu J. 2020. In the Shadow of the Government: The Chinese Nonprofit Sector in the COVID-19 Crisis. The American Review of Public Administration 50(6- 7):784-789.
} 
"administrative absorption of society" ${ }^{67}$

Thus far, it appears that civil society under Xi Jinping faces more constraints than under $\mathrm{Hu}$ Jintao, but also has new opportunities in the realms of fundraising and still offers limited channels for policy advocacy. The codification of CSO legal status, new taxation rules on donations, and the expansion of government contracting have created more diverse funding streams. Additionally, in certain policy areas like the environment, CSOs have gained legal standing to sue local polluters. Consultative Authoritarianism still functions in China, but this model has shifted to less open consultation and the use of more authoritarian tools like repression.

\section{Implications of 'Less Consultation-More Authoritarianism' for Governance}

Xi Jinping's political logic differs from that of both Jiang Zemin and $\mathrm{Hu}$ Jintao in that it focuses more on the centralization of governance under the Party. Xi believes his institutional changes around promotion and anticorruption, along with support from digital governance, ${ }^{68}$ will return enough information to the central government to develop good policies and monitor the behavior of local officials. Although the role for civil society appears much more limited under this centralized governance model, Xi does not seem to want to completely repress or ban CSOs. This new model of 'limited consultation and more authoritarianism' is best understood as a professional contracting relationship rather than one based on advocacy. Larger, older, and more professional CSOs, like Friends of Nature, are allowed a participatory role, such as being allowed to investigate and sue local polluters as well as the government agents that protect them; however, those working on topics deemed solidly under the domain of government or those that

\footnotetext{
${ }^{67}$ Kang Xiaoguang. 2018. Moving toward Neo-Totalitarianism: A Political-Sociological Analysis of the Evolution of Administrative Absorption of Society. Non-Profit Policy Forum 2018.

${ }^{68}$ Gao, Xiang. 2020. State-Society Relations in China's State-Led Digitalization. China Review, 20(3), 1-12.
} 
might challenge state authority face more repression. The tolerance for groups that are grassroots advocacy organizations, or founders who might rhetorically challenge state authority but also run beneficial projects, has disappeared. Although some of the changes under Xi Jinping were necessary to professionalize CSOs and standardize regulations, there is also a danger that they undermine the benefits of the consultative authoritarianism model.

What does this mean for the ability of the new version of the consultative authoritarianism model to improve governance under authoritarianism? Although I cannot predict the future, I would expect that CSOs will still function effectively in China, but only the bigger groups that work more closely with the state through "performance-based collaboration". ${ }^{69}$ Concerned citizens will continue to provide information to improve governance, but mostly in coordination with government agencies or through wellestablished CSOs. ${ }^{70}$ Given the strengths of the more balanced consultative authoritarianism model, this new model will likely provide less information on unintended consequences of policies. Additionally, digital monitoring of measures like environmental targets will only deliver quantitative results, but not necessarily all information required to make good decisions. For example, to meet environmental targets, many officials simply shut down all factories rather than identifying the ones who are trying to improve environmental technology, often leading to unemployment and unrest. ${ }^{71,72}$ This model will still outperform those types of authoritarianism with less information; however, it will not deliver the same governance benefits, resulting in a less responsive state.

${ }^{69}$ Shen, Yongdong and JianxingYu. 2017. Local government and NGOs in China: Performancebased collaboration. China: An International Journal, 15(2), pp.177-191.

${ }^{70}$ Anderson, S. E., Buntaine, M. T., Liu, M., \& Zhang, B. 2019. Non-Governmental Monitoring of Local Governments Increases Compliance with Central Mandates: A National-Scale Field Experiment in China. American Journal of Political Science, 63(3), 626-643.

${ }^{71}$ Gao, X., \& Teets,J. 2020. Civil society organizations in China: Navigating the local government for more inclusive environmental governance. China Information.

${ }^{72}$ Li, Yifei and Judith Shapiro. 2020. China goes Green: coercive environmentalism for a troubled planet. John Wiley \& Sons. 
Outside of China, aspects of this model of consultative authoritarianism have been adopted by over 50 countries, both democracies and autocracies. ${ }^{73,74}$ This mirrors the growing illiberal wave around the world: "Countries that suffered setbacks in 2019 outnumbered those making gains by nearly two to one, marking the 14 th consecutive year of deterioration in global freedom. During this period, 25 of the world's 41 established democracies experienced net losses". ${ }^{75}$ These trends of growing authoritarianism and less consultation with CSOs inside of China and around the world suggest troubling implications for nascent civil societies and responsive governance. Civil society offers reliable information for authoritarian regimes about policy performance, citizen satisfaction, and elite cohesion, and this knowledge then creates more durable regimes by improving performance legitimacy and establishes channels for collaborative governance with active citizens and other elites. Without this, regimes must use increased repression to ensure obedience, which is both more expensive and less successful, and frequently triggers challenges to authoritarian rule. ${ }^{76}$

${ }^{73}$ Gilbert, Leah, and PayamMohseni. 2018. Disablingdissent: the colour revolutions, autocratic linkages, and civil society regulations in hybrid regimes. Contemporary Politics 24.4: 454-480.

${ }^{74}$ Poppe, Annika Elena, and Jonas Wolff. 2017. The contested spaces of civil society in a plural world: norm contestation in the debate about restrictions on international civil society support. Contemporary Politics 23.4: 469-488.

${ }^{75}$ Freedom House. 2020. Freedom in the World 2020: A Leaderless Struggle for Democracy. Accessed August 2020: https://freedomhouse.org/report/freedom- world/2020/leaderless-struggledemocracy

${ }^{76}$ Svolik, MW. 2012 The Politics of Authoritarian Rule. Cambridge and New York: Cambridge University Press. 


\title{
4
}

\section{Authoritarian Capitalism and Its Impact on Business}

\author{
Daniel Kinderman
}

Associate Professor and Director of European Studies Department of

Political Science\& International Relations University of Delaware

\section{Introduction}

The global political order has undergone multiple sea changes in recent decades. With the collapse of the Soviet Union, liberal democracy was widely seen as the "End of History."77 "Free market capitalism looked to have permanently carried the day," 78 and it was thought to be only a matter of time until the world converged on this model. By the 2010s, the tide had turned, and a democratic recession ${ }^{79}$ shattered this liberal-democratic triumphalism and the assumptions that had underpinned it.

${ }^{77}$ Francis Fukuyama, The end of history and the last man. Simon and Schuster, 2006.

${ }^{78}$ Ian Bremmer, The End of the Free Market: Who Wins the War Between States and Corporations, Penguin,2010, 3.

${ }^{79}$ Larry Diamond, "Facing up to the democratic recession" Journal of Democracy 26.1 (2015):141-155. 
The earthquakes of Brexit and Trump are two manifestations of the deeper structural forces which have rendered liberal democracies increasingly unstable, divided, and polarized. ${ }^{80}$ Meanwhile, China's rise suggests an alternative model that embraces capitalism while rejecting or severely restricting political and civil liberties. Without democracy, Singapore has risen to become one of the world's most prosperous and dynamic economies. In both Hungary and Poland, democratic backsliding has taken place under right-wing populist rule.

The authoritarian capitalist model is contentious. Proponents of liberal democracy maintain that the authoritarian capitalist model is dysfunctional. Prominent scholars claim that democracy is better for growth ${ }^{81}$ and that growth in authoritarian countries such as China will run out of steam unless they liberalize politically. ${ }^{82} \mathrm{~A}$ decade ago, one leading commentator wrote, "Free markets provide those who participate in them with long-term advantages that state capitalism can't match." 83

In this essay, I inquire into the relationship between authoritarian capitalism and business and set out to answer the following questions: What happens to the business environment under authoritarian leadership? Is there a tradeoff between authoritarianism and the climate for business? Does democratic recession in liberal democracies have any notable downsides for business?

To answer these questions, I draw on indicators measuring civil and political liberties and corruption on one hand, and the ease of doing business, global competitiveness, and innovation on the other hand. The evidence

${ }^{80}$ Steven Levitsky and Daniel Ziblatt. How democracies die. Crown, 2018; Thomas Piketty, Capital in the Twenty-First Century, Belknap Press of Harvard University Press, 2014, and Thomas Piketty, Capital and Ideology, Belknap Press of Harvard University Press, 2020; Adam Prezworski, Crises of democracy. Cambridge University Press, 2019.

${ }^{81}$ Daron Acemoglu and Suresh Naidu, "Democracy does cause growth" Journal of Political Economy 127.1 (2019):47-100.

82 Daron Acemoglu and James A. Robinson. Why nations fail: The origins of power, prosperity, and poverty. Crown Business, 2012.

${ }^{83}$ Ian Bremmer, The End of the Free Market:Who Wins the War Between States and Corporations, Penguin, 2010, 175. 
suggests two crucial findings. First, key business indicators in China and Singapore have improved significantly despite these countries' persistent authoritarianism. Second, key business indicators in Hungary and Poland have stayed constant or improved, despite growing authoritarianism in these two countries during the past decade. In short, the authoritarian capitalist model does not appear to be dysfunctional or have significant drawbacks for large segments of business.

The section below provides a quick gloss of authoritarian capitalism in Singapore, China, Hungary, and Poland.

\section{Authoritarian Capitalism}

What is authoritarian capitalism? This question is difficult to answer because the group of authoritarian capitalist countries is heterogeneous and not clearly defined. Authoritarian capitalism can include features such as authoritarian shareholding, predatory nationalizations, the extraction of private rents using the state as a tool, the reduction of economic pluralism through the alignment of economic and political interests, as well as state capture by particularistic interest groups and the creation of state dependence of economic actors. These features can result in the erosion of the rule of law and the colonization of the state by the ruling elite, ${ }^{84}$ but softer authoritarian capitalist models can maintain impartial bureaucracies and the integrity of the rule of law.

A defining characteristic of authoritarian capitalism is the presence of a capitalist economy on one hand along with the absence or erosion of democracy and civil liberties on the other hand. Authoritarian capitalism must be carefully distinguished from public ownership, which is unproblematic insofar as state companies are democratically - controlled and accountable. There is nothing per se wrong with public ownership; on what

${ }^{84}$ Dorottya Sallai and Gerhard Schnyder. "What Is "Authoritarian" About Authoritarian Capitalism? The Dual Erosion of the Private-Public Divide in State-Dominated Business Systems." Business E Society (2019). 
grounds is ExxonMobil, Royal Dutch Shell, or BP preferable to Norway's Equinor/Statoil? Especially in a situation in which competition has been weakened and corporate power is highly concentrated - a situation which arguably pertains to the contemporary United States ${ }^{85}$ - there is little to recommend the status quo in comparison to democratically-controlled public ownership.

I identify four examples of authoritarian capitalism: China, Singapore, Hungary, and Poland. These countries vary in several ways. Singapore, under the rule of the People's Action Party, is widely considered an example of 'soft' authoritarianism: 86

Singapore's limited democracy has been singularly successful in producing the national development it has been deliberately designed to produce. It is remarkable that the PAP rulers of Singapore, enjoying almost total power given them by the political system, have administered it without succumbing to any abuse of power, arbitrary rule, corruption, mismanagement or disregard for the interests of Singaporeans. They have always ruled the island state with exceptional integrity, dedication, and respect for the rule of law. 87

According to another scholar,

Singapore has been successful because it has been smart in a dual sense. It has been pragmatic and also technologically empowered.... Singapore policymaking has become smart... Singapore has designed and implemented global best practices in a broad range of areas. ${ }^{88}$

\footnotetext{
85 Thomas Philippon, The great reversal: How America gave up on free markets. Harvard University Press, 2019.

${ }^{86}$ Netina Tan, "Singapore: Challenges of 'Good Governance' Without Liberal Democracy." Governance and Democracy in the Asia-Pacific. Routledge, 2020, pp. 48-73.

87 Raj Vasil, Governing Singapore: Democracy and national development. Routledge, 2020, p. 233

${ }^{88}$ Kent E. Calder, Singapore: Smart city, smart state. Brookings Institution Press, 2016: 164-165.
} 
China, under President Xi Jinping, is an "authoritarian capitalist" model that "mixes developmental with predatory elements and remains highly interventionist" 89; "hard" authoritarian model which combines "hardened political repression ... with very marginal economic reforms"90; a "pragmatic authoritarian" model, ${ }^{91}$ and a "party-state capitalist" model characterized by "party-state encroachment on markets; a blending of functions and interests of state and private ownership; and politicized interactions with foreign capital." 92

Poland and Hungary are both members of the European Union and at least nominally democracies with multiparty elections. Hungary, under Prime Minister Viktor Orbán, presents a stark example of democratic deconsolidation. Orbán is an individual with an "absolute will to power" and a "ruthless chess player of power politics." 93 Over the past decade, Orbán has, with an iron fist, launched a "perpetual war against liberal Western values," constructed a "carefully veiled authoritarian system," communist mafia state." "95 Orbán's "constitutional coup" "96 has tilted the political system strongly in favor of his ruling party Fidesz, which also exerts tight control over the country's news media. Orbán's illiberal revolution has

${ }^{89}$ Michael A. Witt and Gordon Redding. "Authoritarian Capitalism.” In: Michael A. Witt and Gordon Redding (eds.) The Oxford Handbook of Asian Business Systems (2014), p. 26.

90 David Shambaugh, China's future. John Wiley \& Sons, 2016.

${ }^{91}$ Hongyi Lai. China's governance model: Flexibility and durability of pragmatic authoritarianism. Routledge, 2016.

${ }^{92}$ Margaret Pearson, Meg Rithmire, and Kellee Tsai. "Party-State Capitalism in China." Harvard Business School Working Paper 21-065 (2020).

${ }^{93}$ Paul Lendvai, Orbán: Europe's new strongman (Oxford: Oxford University Press, 2018), p. 19, p. 150.

${ }^{94}$ Paul Lendvai, Orbán: Europe's new strongman (Oxford: Oxford University Press, 2018), p. 205, p. 53.

${ }^{95}$ Balint Magyar, Post-communist Mafia state: The case of Hungary (Budapest: Central European University Press, 2016).

${ }^{96}$ Kim Lane Scheppele, Worst Practices and the Transnational Legal Order (or how to build a constitutional 'democratorship' in plain sight) Background Paper: Wright Lecture, University of Toronto, 2016. 
weakened the independence of the judiciary ${ }^{97}$ and resulted in an exceptional concentration of power. ${ }^{98}$ Critics have charged that since pluralism is an essential prerequisite of democracy, Orbán's "moralized anti- pluralism"99 is not just illiberal, it is anti-democratic.

Poland's right-wing populist Law and Justice (PiS) government, under the leadership of Jarosław Kaczyński, has often been compared to Orbán's Hungary because of the democratic backsliding that has taken place in both countries. In power since 2015, the PiS government has put pressure on oppositional media outlets, weakened minority rights, and dismantled institutional checks and balances through changes to the judiciary, in particular the Constitutional Tribunal. ${ }^{100}$

\section{Indicators of Democracy, Civil Liberties, and Corruption}

This section shows how China, Singapore, Hungary, and Poland score according to widespread indicators of democracy, civil liberties, and corruption. We begin with the Freedom House ratings for civil liberties and political rights, which range from 1 to 7 , "with1 representing the greatest degree of freedom and 7 the smallest degree of freedom." 101

\footnotetext{
${ }^{97}$ Takis Pappas, Populism and Liberal Democracy: A Comparative and Theoretical Analysis (Oxford: Oxford University Press, 2019), pp. 204-205.

${ }^{98}$ Péter Krekó and Zsolt Enyedi, “Explaining Eastern Europe: Orbán's Laboratory of Illiberalism” Journal of Democracy, Volume 29, Number 3, July 2018, pp. 39-51.

99 Jan-Werner Müller, What Is Populism? (Philadelphia: University of Pennsylvania Press, 2016).

${ }^{100}$ For a useful account of Poland, see Wojciech Przybylski, "Explaining Eastern Europe: Can Poland's Backsliding Be Stopped?” Journal of Democracy 29, no. 3 (2018): 52-64.

${ }^{101}$ https://freedomhouse.org/reports/freedom-world/freedom-world-research$\underline{\text { methodology }}$
} 


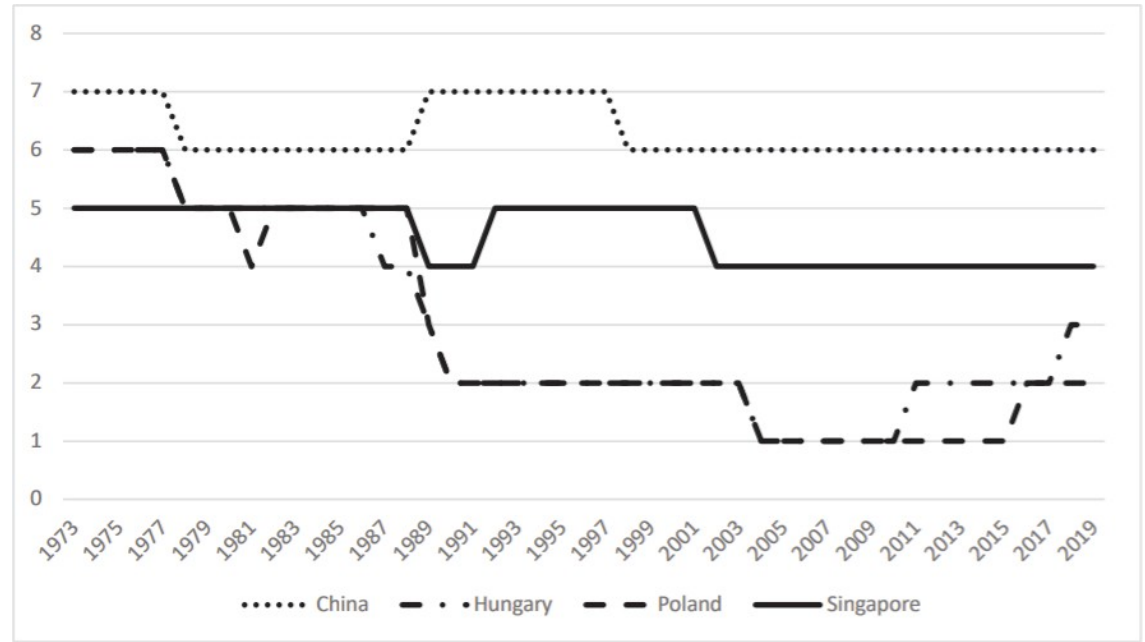

Figure 1: Freedom House Civil Liberties, 1973-2019

Source: Freedom House 


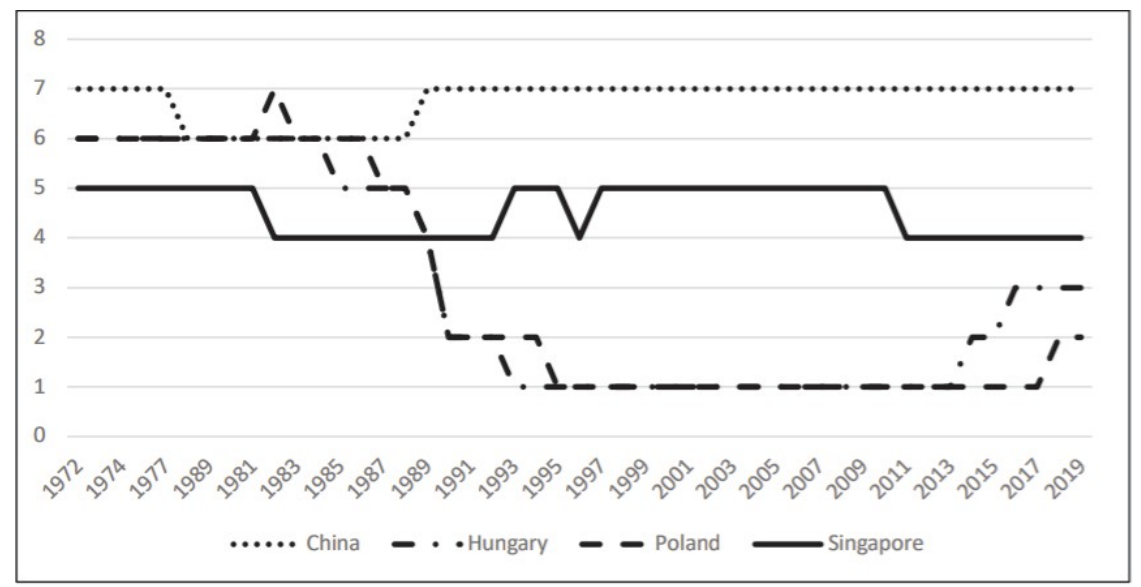

Figure 2: Freedom House Political Rights, 1972-2019

Source: Freedom House

As we can see in Figures 1 and 2, China has remained in the Not Free category regarding both civil liberties and political rights over the past five decades. Singapore, by contrast, is Partially Free. From the 1990s through the 2010s, Poland and Hungary had become fully Free, but by the 2010s, both were regressing under right-wing populist rule, so that by 2016-2018, Hungary was Partially Free in both categories. In Poland, the movement has been smaller, but in the same direction.

Next, we examine Transparency International's Corruption Perceptions Index, which "uses a scale of zero to 100 , where zero is highly corrupt and 100 is very clean." 102

102 https://www.transparency.org/en/news/cpi-2019-global-highlights 


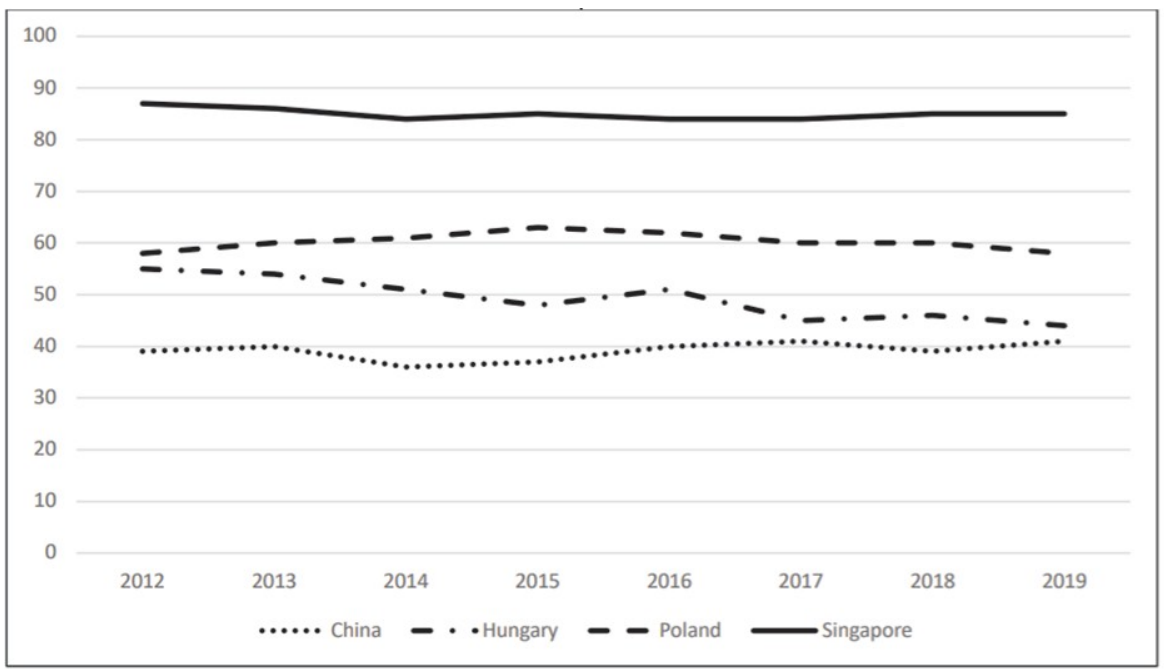

Figure 3: Transparency International Corruption Perceptions Index, 2012-2019

Source: Transparency International

Singapore has consistently been one of the least corrupt jurisdictions in the entire world. China is much more corrupt. Under right-wing populist rule, corruption has increased in both Hungary and Poland - quite dramatically in the former, and to a lesser extent, but still noticeably in the latter. Although there is substantial variation within the group of authoritarian capitalist nations, these regimes score poorly when it comes to political rights and civil liberties. Singapore is squeaky clean, but the other three countries have problems with corruption. Authoritarianism has had an effect on politics and society in these countries, but has it also had an adverse impact on the business environment? We will find out in the next section.

\section{The Business Environment under Authoritarian Capitalism: The Ease of Doing Business, Competitiveness, and Innovation}

Leading commentators have suggested that authoritarianism adversely affects the business environment - however, is that really the case? We begin with 
the World Bank's Doing Business index, which provides a commonly used measure of business regulation, the ease at which small domestic firms can conduct business in the largest business city in each economy. Figures 4, 5, and 6 show the progression of China, Hungary, Poland, and Singapore. Figures 4 and 5 provide the raw scores, while Figure 6 provides these countries' rankings. The World Banks' methodology for the Doing Business index changed between 2011 and 2014, which explains the two-year data gap between Figure 4 and Figure 5.

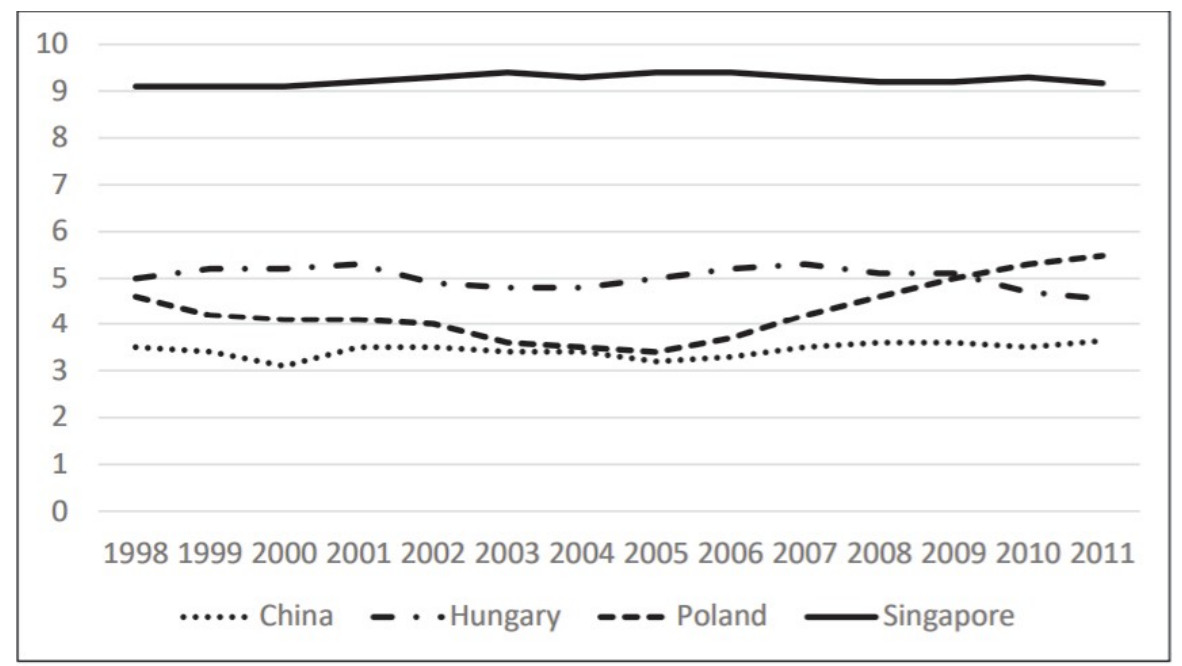

Figure 4: World Bank's Doing Business Index, 1998-2011

Source: World Bank 


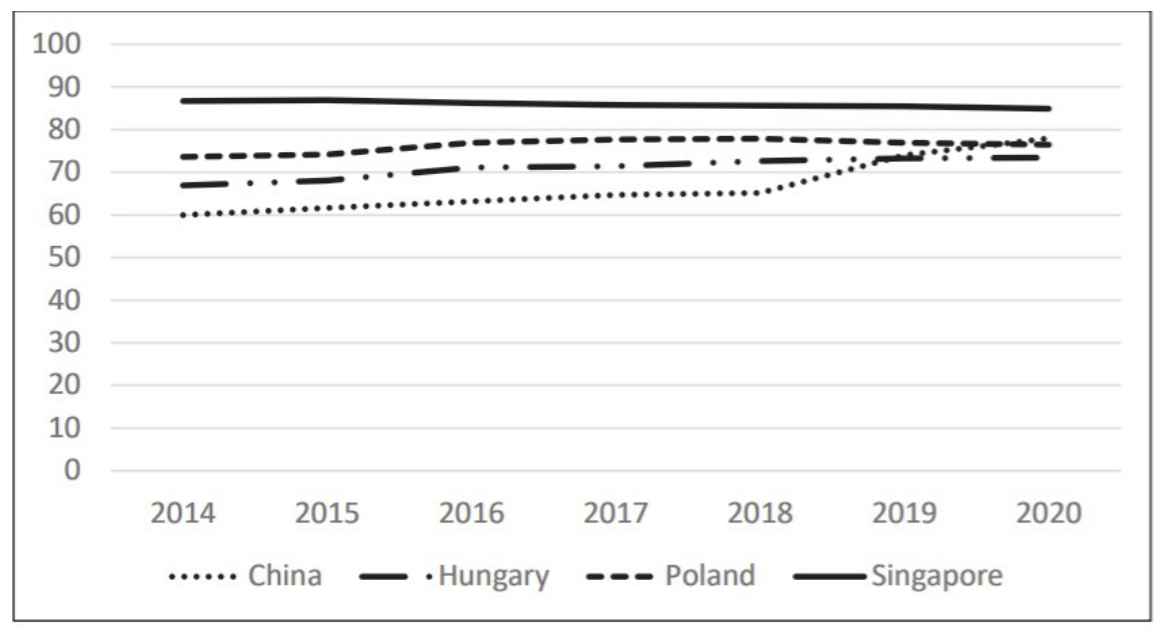

Figure 5: World Bank's Doing Business Index Scores, 2014-2020

Source: World Bank

Singapore has consistently had a very high doing business score-one that places it at the top of the world, as we will see below. China's raw score remained relatively constant from 1998 to 2011 but has improved significantly between 2014 and 2020. Poland's score increased significantly before the current PiS government, but both Poland and Hungary's raw scores have continued to improve under right-wing populist rule. Authoritarian politics does not necessarily entail illiberal economic or business policy. Figure 6 shows how these countries rank in comparison with others across the world. 


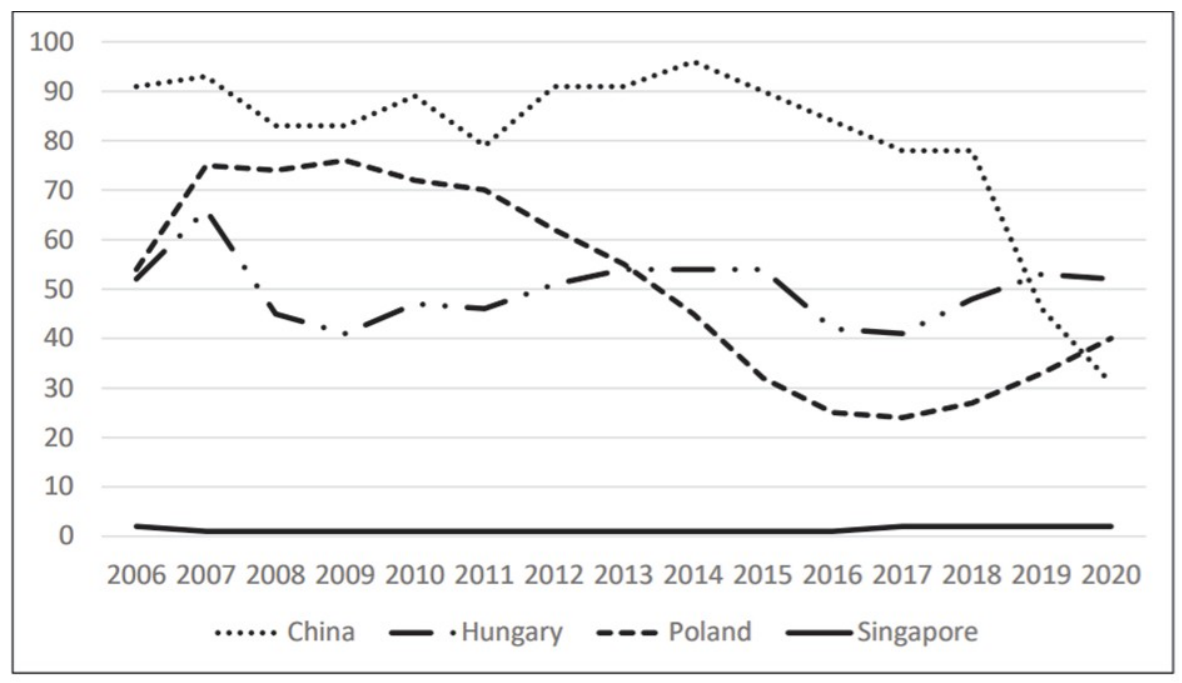

Figure 6: World Bank's Doing Business Index Rankings, 2006-2020

Source: World Bank

For ten of the fifteen years covered in Figure 6, Singapore has ranked \#1 in the world in the doing business index; in the remaining five years, Singapore ranked\#2 in the world. Figure 6 shows that both Singapore's soft, technocratic authoritarianism and China's hard authoritarianism can be very good for business: China's ranking improved dramatically, from \#96 in 2014 and \#78 in 2018 to\#31 in 2020. China's hard authoritarianism has not stood in the way of growing business friendliness in recent years and decades.

The situation in right-wing populist Poland and Hungary is more mixed. Poland's ranking improved significantly from \#76 to \#32 in 2015, when the current PiS government came to power. Under right-wing populist rule, Poland's ranking continued to improve at first, before deteriorating in the last two years. In 2020, Poland was ranked lower than it was in 2015. Not all authoritarian and right-wing populist governments are business-friendly. During the past decade, under Prime Minister Viktor Orbán’s rule, Hungary’s doing business index ranking has fluctuated around the same level. Hungary's 
ranking has not improved despite Orbán’s business-friendly orientation. ${ }^{103}$

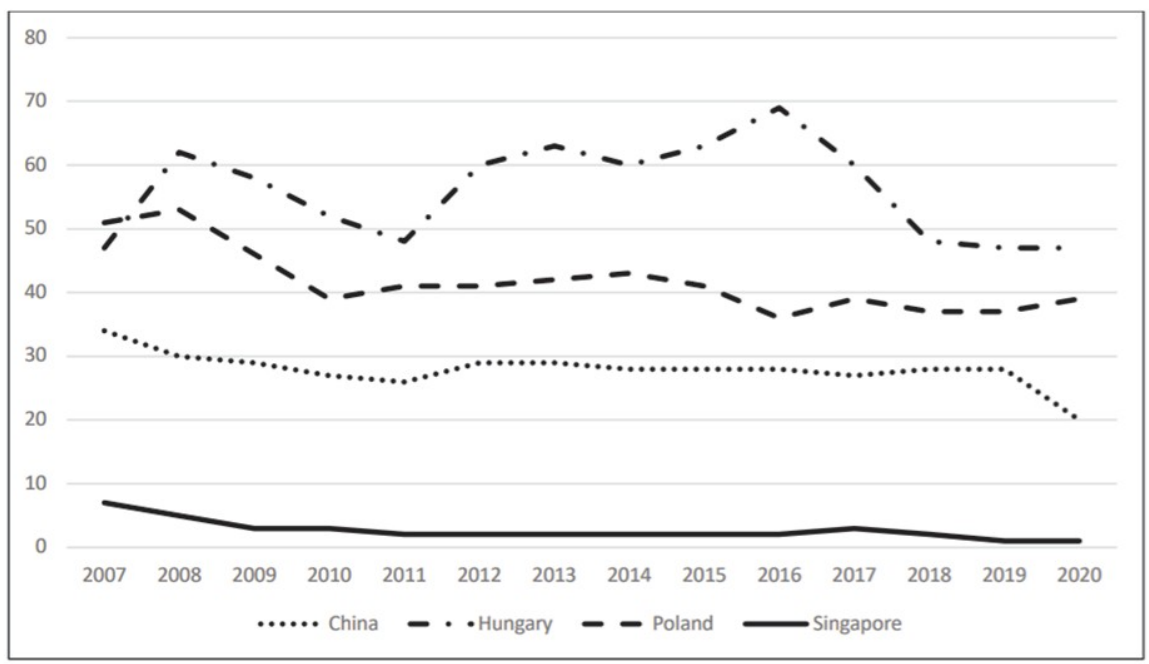

Figure 6: Global Competitiveness Index Ranking, 2007-2020

Source: World Economic Forum

While the value of competitiveness is not undisputed, ${ }^{104}$ it is important for companies in the tradeable sector and in small, open economies. Singapore has long been ranked one of the world's most competitive economies, and at the time of writing, Singapore ranked \#1 in the world. China's ranking has also improved substantially. Poland and Hungary's competitiveness rankings both improved marginally following right-wing populist rule.

Finally, we draw on the Global Innovation Index rankings to examine the innovation performance of these four countries. The repression of political and civil liberties could plausibly have had a damaging effect in innovation. In this vein, five years ago, some scholars made the following remarks about

\footnotetext{
${ }^{103}$ See Gábor Scheiring, The retreat of liberal democracy: Authoritarian capitalism and the accumulative state in Hungary Palgrave, 2020.

${ }^{104}$ Paul Krugman, “Competitiveness: a dangerous obsession” Foreign Affairs 73 (1994): 28.
} 


\section{AUTHORITARIAN CAPITALISM AND ITS IMPACT ON BUSINESS}

China:

The needs of a middle income country, including greater reliance on innovation in technology and business models, and an increasingly diverse and sophisticated consumption demand, seem ill-suited for the still very sophisticated for the still very centralized model of Chinese state capitalism. Still, with its remarkable ability to reshape institutions, to experiment, and to use its size and diversity to its advantage, China has surprised us many times before. ${ }^{105}$

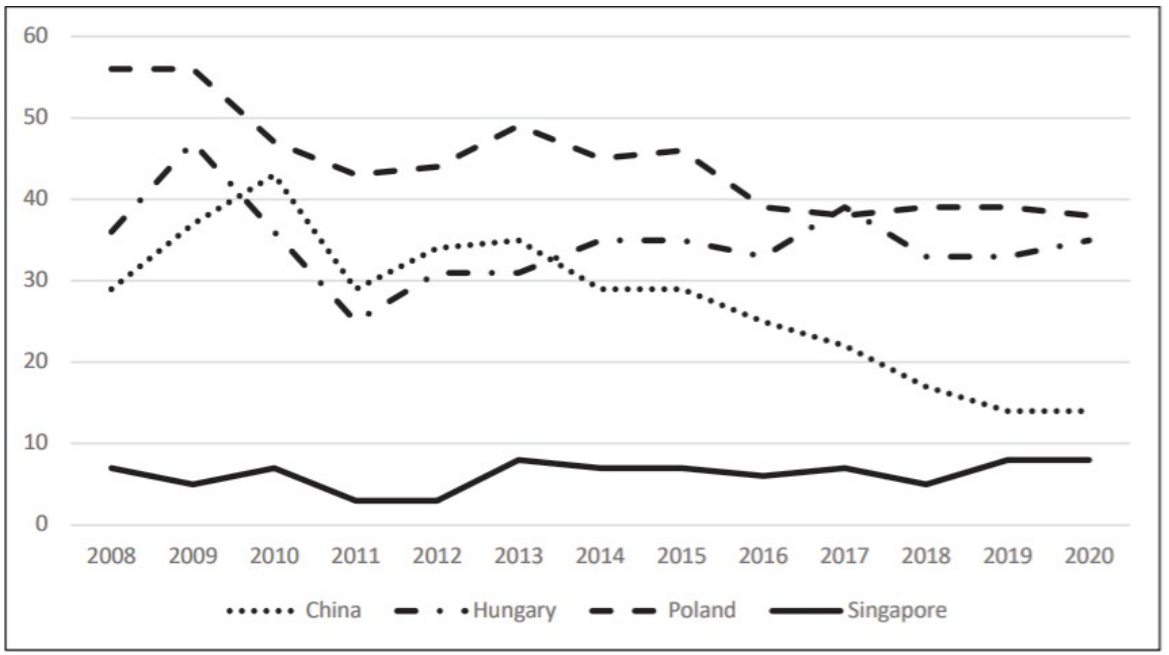

Figure 7: Global Innovation Index Rankings, 2008-2020

Source: Global Innovation Index

The above authors' cautionary note was wise considering China's dramatic

105 Tsai, Kellee S., and Barry Naughton. "State capitalism and the Chinese economic miracle." B. Naughton, KS Tsai, eds Naughton, Barry, and Kellee S. Tsai, eds. State capitalism, institutional adaptation, and the Chinese miracle. Cambridge University Press, 2015. (2015): 21. 
innovation performance improvement during the past five years. ${ }^{106}$ Singapore has fluctuated but remains solidly in the top 10. Poland's innovation performance has improved under PiS rule, while Hungary's ranking has remained around the same level under Orbán.

To sum up this section, the four authoritarian capitalist countries surveyed in this essay perform as follows: Singapore leads the world when it comes to competitiveness and the ease of doing business. Singapore's innovation performance is lower but consistently among the top 10 in the world. China's ease of doing business performance and ranking as well as its innovation index ranking have improved dramatically in recent years. Hungary and Poland's performances have wavered under right-wing populist rule, but they have not significantly deteriorated.

\section{Conclusions and Reflections}

Faced with the challenge posed by authoritarian capitalism, proponents of liberal democracy have consistently maintained that liberal democracy is better for business than authoritarian capitalism. We can see this in the following example:

Had Singapore been a liberal democracy, however, these difficulties might never have emerged in the first place. Even today, a freer society is likely to be more effective than more economic tinkering by the government in ensuring the country's future prosperity. That is the economic case for liberal democracy in Singapore. ${ }^{107}$

Since these remarks were made a decade ago, Singapore's performance has remained outstanding and China has made dramatic improvements. Hungary

${ }^{106}$ See also Li, Zheng, et al. "China's 40-year road to innovation." Chinese Management Studies (2019); and Yu Zhou, William Lazonick, and Yifei Sun, eds. China as an innovation nation. Oxford University Press, 2016.

${ }^{107}$ Marco Verweij and Riccardo Pelizzo. "Singapore: does authoritarianism pay?.” Journal of Democracy 20.2 (2009): 31. 
and Poland's performances have fluctuated, but they have not significantly deteriorated under right-wing populist rule. In short: authoritarian leaders in these four countries have fostered a very good and increasingly attractive business environment.

The strong performance of authoritarian capitalist countries is not exactly news. After the Great Recession of 2008, there was recognition that, "Oneparty autocracy certainly has its drawbacks. But when it is led by a reasonably enlightened group of people... it can also have great advantages." 108 Further, in light of Singapore's success there is widespread acknowledgment that "liberal democracy is neither a necessary nor sufficient condition for good governance or prosperity."109

I wish to clarify that I am not arguing that authoritarian capitalism is necessarily successful or good for business. Autocrats and right-wing populists can be harmful and damaging; when businesspeople perceive them in this way, they can mobilize against them. ${ }^{110}$ But this should not be our default assumption as authoritarian regimes have become increasingly businessfriendly across the world.

I am also not claiming that businesspeople would opt for an authoritarian regime if given a full menu of options. Political and civil liberties are important to citizens, and many businesspeople have an interest in a liberal institutional environment which empowers them politically. Ceteris paribus - all other things being equal — capitalist firms may well prefer liberal democracy to authoritarian governance. However, in the real world, all other things are not equal. Authoritarian governments may be sufficiently repressive that domestic firms in these countries do not have much of a choice other than working with the powers-that-be.

Businesses from Western Europe and the United States could exit from

${ }^{108}$ Thomas Friedman, “Our one-party democracy” New York Times 8 (2009): A29.

${ }^{109}$ Netina Tan, "Singapore: Challenges of 'Good Governance’ Without Liberal Democracy." Governance and Democracy in the Asia-Pacific. Routledge, 2020, 50.

${ }^{110}$ Daniel Kinderman, "German Business Mobilization against Right-Wing Populism.” Politics \& Society (2020) https://doi.org/10.1177/0032329220957153 
Singapore, Hungary, Poland, or China if their investments in these countries were not worthwhile or engagement in these countries was too unsavory on account of corruption, repression, or other grounds-but they do not. Businesses' institutional preferences are malleable and business support can often be 'bought' with the right incentives, i.e. profits or rents. ${ }^{11}$

Political developments in recent years have significantly weakened the business case for liberal democracy and, as a result, proponents of democracy may need to re-think some of their arguments. As Cherian George has suggested, the "good governance" practiced by authoritarian states such as Singapore significantly weakens the instrumental justification for democracy. ${ }^{112}$ Supporters of liberal democracy should not argue that liberal democracy is preferable because it is better for business than authoritarian capitalism, since it is far from obvious whether that is correct; in fact, the reverse may now be true.

The fact that authoritarian regimes have substantial business support suggests that democracy restson a shaky political-economic foundation. To the extent that that is true, the future is wide open between alternative paths: a further deepening of authoritarian capitalism ${ }^{113}$ could lead to more improvement of the business environment, or a move away from capitalism could help to save democracy. It is too early to tell if liberal democracy can be stabilized and reconciled with capitalism and made to flourish again, as was the case in the post-war order ${ }^{114}$ or whether the road ahead is instead "a

\footnotetext{
${ }^{111}$ Future research could aim to compare the profit rates of firms under authoritarian capitalism and liberal democracy.

${ }^{112}$ Cherian George, "Neoliberal "Good Governance" in Lieu of Rights: Lee Kuan Yew's Singapore Experiment." In: Monroe Price and Nicole Stremlau, eds. Speech and Society in Turbulent Times. Cambridge University Press (2017): 114-130.

${ }^{113}$ Peter Bloom, Authoritarian capitalism in the age of globalization. Edward Elgar Publishing, 2016.

${ }^{114}$ Sheri Berman, Democracy and dictatorship in Europe: from the Ancien Régime to the Present Day. Oxford University Press, 2019.
} 


\section{AUTHORITARIAN CAPITALISM AND ITS IMPACT ON BUSINESS}

long and painful period of cumulative decay." 115 In any case, supporters of democracy will need to make a stronger case for its intrinsic, rather than its instrumental value. ${ }^{116}$

${ }^{115}$ Wolfgang Streeck, How will capitalism end?: Essays on a failing system. Verso Books, 2016, p. 72.

${ }^{116}$ Amartya Kumar Sen, "Democracy as a universal value" Journal of Democracy 10.3 (1999): 3-17. 


\title{
Impact of Authoritarian Trends and Political Tribalism on Muslim Minorities in the US
}

\author{
Asma T. Uddin \\ Inclusive America Project Fellow \\ Aspen Institute
}

\section{Introduction}

Donald Trump's presidency might be coming to a close, but the forces that elected him and continue to trumpet Trumpism are still very much influential. To counter Trump's appeal, we have to start by understanding it.

With that goal in mind, it helps to divide Trump's base into categories of concerns. This paper looks at the religious piece of the puzzle- the now infamous $81 \%$ of white evangelicals who helped elect him and were the focus of many of his policies and much of his pandering. This paper also examines the relationship between these evangelicals and Muslims as religious minorities. President Trump, after all, made Muslims one of the primary targets of his vitriol, and evangelicals reflected that same hostile attitude. While there are many drivers of this antagonism, this paper analyzes 
the impact of political tribalism - informed by group dynamics and social psychology — on how evangelicals perceive and react to Muslims.

\section{Group Identity and Intergroup Bias}

I once asked a roundtable of people who work on religious engagement programs and religious freedom advocacy whether political tribalism drives anti-Muslim hostility among white evangelicals. One person responded, "Definitely. Everything is tribal nowadays. Muslims are part of a different religious tribe and inasmuch as they align with progressives, a different political tribe also." Another stated, "Yes. [Conservative white evangelicals] believe Democrats are trying to encourage Muslim immigration because it will help them de-Christianize America."

To understand this dynamic, it is helpful to have a basic understanding of group identity. Much of what we know about group dynamics is based on a series of experiments conducted by social psychologist Henri Tajfel in the 1970s. In one study, he took sixty-four boys from the same school; the boys all knew each other and already had a sense of community among them. First, the researchers told the boys they wanted to test visual judgment. The boys were shown clusters of dots and had to estimate how many dots they saw. After the researchers tallied (or pretended to tally) the results, the researchers informed the boys that they were dividing them into groups: one included boys who had guessed a high number of dots on the visual judgment test and another consisted of those who had guessed low. In reality, the researchers divided the boys randomly; their purpose was only to test what happened next.

The researchers then gave the two groups some money and asked them to distribute it to other boys in the study. The boys couldn't keep any money for themselves; they had to give it to the others, but they chose how they would allocate the money and they knew if it went to members of their own group or the out-group. What Tajfel learned from the study shocked him about the power of group identity. Most of the boys in each group gave money to their own group members instead of to the out-group. The boys had been divided 
on the basis of completely meaningless criteria, but they still chose their own group over the other one. There was no substantive benefit to choosing their own group, but they still did it because of the powerful pull of group identity.

In a second study, Tajfel changed the setup so that when the boys were allocating money, they had to choose between maximizing their own amount of money and maximizing how much more their group got compared to the out-group. The boys chose the latter. The boys were okay with giving their own group less so long as they had significantly more money than the out-present political climate, these group rivalries pose ever more serious implications because of what Lilliana Mason in Uncivil Agreement: How Politics Became Our Identity(2018) calls the emergence of "mega- identities": "A group. As a series of subsequent single vote can now indicate a person's partisan preference as well as his or her experiments by Tajfel and others confirmed, people exhibit discriminatory intergroup behavior in a way that created the biggest gap between their group and the out-group: "Far from the money being the prime motivator, 'it is the winning that seems more important to them.",

\section{Intergroup Bias and US Partisanship}

Our allegiance to our political tribes is no different than the usual dynamic of group loyalty and intergroup bias. Elections are pure team rivalry. What is worse, however, is that in our religion, race, ethnicity, gender, neighborhood, and favorite grocery store. This is no longer a single social identity. Partisanship can now be thought of as a mega-identity, with all the psychological and behavioral magnifications that implies."

It is the difference between sorting and polarizing. The first is issue-based polarization - we cluster together based on our policy opinions. The second is identity-based polarization - we cluster together based on political identities. "[O]ur political identities are polarizing our other identities, too," and issue conflicts are just one of many expressions of that hostility.

In this ever-widening circle, almost nothing is apolitical anymore. Consider a 2004 ad by the Club for Growth, a conservative group that advocates for 
lower taxes and deregulation, against then-presidential candidate Howard Dean. The ad features someone asking an older white couple what they think of Dean's plan, and the man responds: "'I think Howard Dean should take his tax-hiking, government- expanding, latte-drinking, sushi-eating, Volvo-driving, New York Times- reading-.' His wife cuts in, 'Body- piercing, Hollywood-loving, left-wing freakshow back to Vermont, where it belongs.", Each of these traits reinforces a particular mega-identity, and when you activate one, you activate them all.

Something like this appears to be at work when it comes to Muslims and liberals. Eboo Patel begins to get at this in Out of Many Faiths: Religious Diversity and the American Promise (2018), where he notesthat Muslims are given platformsby outlets like The New York Times, NPR, CNN, The New Yorker - outlets that are associated with urban, multicultural, progressive Whole Foods America; not so much white, rural, conservative Cracker Barrel America. One gets the sense that if Trump's America insists on casting Muslims as villains... then Barack Obama's America will respond by promoting Muslims whom they consider heroes ... Muslims, in other words, have become a totem in the current chapter of the American culture wars, a symbol that signals, above all, a tribal belonging (Trump/red/rural/evangelical/Cracker Barrel versus Obama/blue/urban/secular/Whole Foods), with each tribe doing its best to foist on the category "Muslim" its preferred set of characteristics. ${ }^{117}$ In other words, Muslims - and especially liberal advocacy on behalf of Muslims - are traits of the liberal mega-identity and opposition to Muslims is a trait of the conservative mega-identity. What happens when American Muslims get lumped into a liberal mega-identity (that is, furthermore, defined by conservatives as anti-Christian and antiAmerica)? Muslims take on those traits, too.

The psychological implications are very dangerous, Mason says. When our racial, religious, and other identities are wrapped up with our political party, the impact on us psychologically is a lot worse if our party loses an election or

\footnotetext{
${ }^{117}$ Patel, Eboo. 2018. Out of Many Faiths: Religious Diversity and the American Promise. Princeton: Princeton University Press.
} 
some other partisan battle. ${ }^{118}$ It is akin to our losing the competition between racial and religious groups, too. It makes us feel threatened and we lash out against the out-group.

This is particularly the case now as many white Christian conservatives are feeling under siege. In-group favoritism does not always result in outgroup bias but, in the religious context, tribalism has resulted in out-group hostility — and Muslims are one of the primary targets of this hostility.

\section{Perceptions of Threat: The End of White Christian America}

Perceptions of threat partly explain this phenomenon. Oxford political scientists Miles Hewstone, Mark Rubin, and Hazel Willis write, "The constraints normally in place, which limit intergroup bias to in-group favoritism, are lifted when out-groups are associated with stronger emotions." Stronger emotions include feelings like the out-group is moving against you: "an out-group seen as threatening may elicit fear and hostile actions." Whereas "high status" groups (those that are a numerical majority and have power) don't feel threatened by minorities when the status gap is very wide, they are more likely to feel vulnerable when the status gap is closing.

There are multiple demographic trends contributing to white evangelicals' perception of threat. For instance, and for the first time in US history, white racial dominance is on the decline. In 1965, white Americans constituted 84 percent of the US population. Since then, there has been an influx of immigrants, with nearly 59 million arriving in the last fifty years alone. Between 1965 and 2015, the American Asian population went from 1.3 million to 18 million, and the Hispanic population went from 8 million to almost 57 million. America'scomplexion is "browning" and in several states-including America's most populous ones, Texas and California — whites are already a minority. National Public Radio reported in 2016 that non-white babies now

\footnotetext{
${ }^{118}$ YouTube. 2018. "Lilliana Mason on Uncivil Agreement.” Last modified May 1, 2020. https://www.youtube.com/watch?v=TC4SQ9oasnU
} 
outnumber non- Hispanic white babies. ${ }^{119}$ The majority of Americans under the age of 16 are non-white (and have been since the middle of 2020). ${ }^{120} \mathrm{Pew}$ says whites generally will be a minority by $2055 ;^{121}$ the US Census says it will happen even sooner, in 2044. ${ }^{122}$

Second, and also for the first time in US history, white Protestant Christians are a minority in America. A 2017 PRRI study found that white Protestant Christians constitute only $43 \%$ of the US population. Robert Jones, the founder of PRRI, calls it the "end of White Christian America." 123 To understand the gravity of the shift, consider that in 1976, eight in 10 Americans were white Christians, and 55\% of Americans were white Protestants. In 1996, white Christians still made up two-thirds of the population. Today, they do not even constitute a majority. Among these white Protestants, white evangelicals have also seen a precipitous drop. In the 1990s, white evangelicals constituted $27 \%$ of the US population; today it is somewhere between $17 \%$ and $13 \% .^{124}$

Third, the demise of white Protestant America has brought with it an end to "the cultural and institutional world built primarily by white Protestants that dominated American culture until the last decade." Not only is Christianity

119 Yoshinaga, Kendra. "Babies of Color Are Now the Majority, Census Says." National Public Radio, July 1, 2016. https://www.npr.org/sections/ed/2016/07/01/484325664/babies-ofcolor-are-now-the-majority-census-says

${ }^{120}$ Schneider, Mike. 2020. "Census shows white decline, nonwhite majority among youngest." Associated Press, June 25, 2020. https://apnews.com/a3600edf620ccf2759080d00f154c069

${ }^{121}$ Pew Research Center. 2015. "Modern Immigration Wave Brings 59 Million to U.S., Driving Population Growth and Change Through 2065." Last modified September 28, 2015. https://www.pewresearch.org/hispanic/2015/09/28/modern-immigration-wave-brings- 59million-to-u-s-driving-population-growth-and-change-through-2065/\#post-1965immigration-drives-u-s-population-growth-through-2065

${ }^{122}$ US Census. 2014. "Projecting Majority-Minority.” https://www.census.gov/content/dam/Census/newsroom/releases/2015/cb15-tps16_graphic.pdf

${ }^{123}$ Jones, Robert P. 2016. End of White Christian America. New York: Simon \& Schuster.

124 Sherwood, Harriet. 2018. "“Toxic Christianity': the evangelicals creating champions for Trump." Guardian, October 21, 2018. https:/www.theguardian.com/usnews/2018/oct/21/evangelical-christians-trump-liberty-university-jerry-falwell 
declining, but so is religion overall. More and more Americans are religiously unaffiliated (the so-called"nones"), and in 2019 the percentage of nones became roughly the same as the percentage of evangelicals or Catholics. ${ }^{125}$ (By 2016, the nones already constituted the nation's largest religious voting bloc.) ${ }^{126}$ The massive shift signaled growing discontent with organized religion generally. Altogether, Jones says, this has precipitated an "internal identity crisis" that has generated tremendous anger, insecurity, and anxiety. Unfortunately, that anger has been directed outwards toward a number of minority groups-Muslims included.

\section{Impact on Religious Minorities: Dismissiveness about Anti-Muslim Discrimination}

There are several theories regarding why threat leads to bias. One is Tajfel's social identity theory. When a high-status group protects its members, the members feel greater self-esteem. When that status is challenged, members feel depressed and lash out at the threatening out-group. There are studies on two closely related social-psychological traits that posit something similar.

\section{Social Dominance Orientation}

The first trait is social dominance orientation (SDO), or a desire to want one's group to dominate the out-group. Feelings of vulnerability make this tendency worse. Scholars have tested the connection between SDO and support for Trump. Professors Rogers M. Smith and Desmond King write that a "wide variety of studies, including experimental research, public opinion surveys, analyses of voting statistics, and panel studies show that [Trump's]

\footnotetext{
${ }^{125}$ Smith, Samuel. 2019. "Religious 'nones' now as big as evangelicals in the US, new data shows." Christian Post, March 20, 2019. https://www.christianpost.com/news/religious-nones-nowas-big-as-evangelicals-in-the-us-new-data-shows.html

${ }^{126}$ Ingraham, Christopher. 2016. "The non-religious are now the country's largest religious voting bloc." Washington Post, July 14, 2016. https://www.washingtonpost.com/news/wonk/wp/2016/07/14/the-non-religiousare-now-the-countrys-largest-religious-voting-bloc/
} 
victim narrative connected powerfully with those with strong attachments to traditionally dominant identities." 127 Political scientist Diana C. Mutz found these trends even among people who in past elections might not have voted for Trump. People who felt their status was threatened experienced an increase in SDO - that is, a desire to dominate the out-group - which in turn led them to "defect to Trump." 128 Mutz tested this specifically with respect to attitudes toward Muslims. Respondents were asked to what extent Muslims and Christians (among others) were discriminated against in America. She found that people who voted for Trump perceived Christians as experiencing greater discrimination than Muslims. Other studies, while not connecting it to SDO specifically, have also documented the partisan divide when it comes to attitudes about anti-Muslim discrimination. In 2020, the University of Chicago Divinity School and the Associated Press-NORC Center for Public Affairs Research(AP-NORC) found that while half of Americans believe that American Muslims' religious freedom is threatened at least somewhat, only about 3 in 10 white evangelicals said the same. ${ }^{129}$ In 2019, Pew found that Democrats and those who lean Democratic "are more likely than Republicans and Republican leaners to say Muslims face at least some discrimination in the U.S. (92\% vs. 69\%)... At the same time, Republicans are much more likely than Democrats to say evangelicals face discrimination (70\% vs. $32 \%)$." 130

In 2017, the Rasmussen Report found that "[fifty-six percent $(56 \%)$ of Democrats ... believe most Muslims in this country are mistreated, a view

127 Smith, Rogers M. and Desmond King. "White Protectionism in America." doi:10.1017/S1537592720001152

${ }^{128}$ Mutz, Diana C. "Status threat, not economic hardship, explains the 2016 presidential vote." Proceedings of the National Academy of Sciences May 2018, 115 (19) E4330-E4339; DOI:10.1073/pnas.1718155115

${ }^{129}$ Schor, Elana and Hannah Fingerhut. 2020. "Religious Freedom in America: Popular and Polarizing." The Telegraph, August 5, 2020.

${ }^{130}$ Masci, David. 2019. "Many Americans see religious discrimination in U.S.- especially against Muslims.” Pew Research Center, May 17, 2019. https://www.pewresearch.org/facttank/2019/05/17/many-americans-see-religious-discrimination-in-u-s-especially-againstmuslims/ 
shared by only $22 \%$ of Republicans." 131 That same year, PRRI found that Democrats were four times as likely to believe that Muslims faced greater discrimination than Christians. Republicans thought the two groups suffered roughly equally, but among white evangelicals specifically, PRRI found that 57 percent said that anti-Christian discrimination is widespread in the US while only 44 percent said the same thing about anti-Muslim discrimination. ${ }^{132}$

Similar to Mutz's findings, there appeared to be a correlation between the political climate and perceptions of status threat. Polls from several years or even a year before the 2016 presidential election found that fewer white evangelicals thought they faced more discrimination than Muslims. A 2013 PRRI survey found that 59 percent of white evangelicals thought Muslims faced more discrimination than evangelicals did; 56 percent responded that way to an October 2016 poll. By February 2017, that number had dropped 12 percentage points. ${ }^{133}$

\section{Authoritarianism}

Scholars have separately studied a second social-psychological trait called "authoritarianism," which refers to a personality type that sees the world as black-and-white and society as fragile, seeking to impose hierarchy, order, and uniformity. In a study published in 2011, Marc Hetherington and Elizabeth Suhay tested the connection between authoritarianism and perceptions of threat from terrorism and found that people who score high on authoritarianism do not "become more hawkish or less supportive of civil

${ }^{131}$ Rasmussen Reports. 2017. "Democrats Think Muslims Worse Off Here Than Christians Are in Muslim World." Last modified February 7, 2017. https://www.rasmussenreports.com/public_content/politics/general_politics/february_2017/democrats_think_muslims_worse_off_here_than_christians_are_in_muslim_world

132 Cox, Daniel and Jones, Robert P. 2017. "Majority of Americans Oppose Transgender Bathroom Restrictions.” PRRI, March 10, 2017. https://www.prri.org/research/lgbttransgender-bathroom-discrimination-religious-liberty/

133 Green, Emma. 2017. "White Evangelicals Believe They Face More Discrimination Than Muslims." The Atlantic, March 10, 2017. https:/www.theatlantic.com/politics/archive/2017/03/perceptions-discrimination-muslims-christians/519135/ 
liberties in response to a perceived threat of terrorism"; they hold these positions even in the absence of threat. However, people "who are less authoritarian adopt more restrictive and aggressive policy stands when they perceive a threat from terrorism. In other words, many average Americans become susceptible to 'authoritarian thinking' when they perceive a grave threat to their safety." 134

A similar tendency comes into play when Christians feel threatened about their status in the US - they begin to acquiesce to the views of Christian nationalists (those who seek to define America as a Christian nation and exclude minorities like Muslims from the national fabric). Political scientist Andrew Lewis explained it to me this way: "Those who are constantly inundated with perspectives that Christianity is threatened (even if they are not necessarily hostile to other religious faiths) are more likely to accommodate Christian nationalist views on their own side. Trying to push back against nationalism from your team and religious discrimination on the other team is a difficult path to follow." 135 That is, it is difficult for many non-nationalists to both resist liberals' attacks on their Christian practices and also resist Christian nationalists' push to privilege Christianity. So, they accommodate the rhetoric and tactics of the Christian nationalists, even if they are more open to diverse faiths.

Importantly, Lewis says, "All of this is wrapped up in partisanship, as partisan leaders prime these responses - both out-group intolerance and ingroup protection. In some eras, partisans have played homage to protecting Christians from losing ground to secularism or liberals. But now partisans on the Right are increasingly emphasizing both secularism and liberalism, as well as Islam and other foreign religions." This explainsMutz's findings, too-Trump's deft use of the victim narrative helped attract voters who were experiencing status threat. On the campaign trail, he told them in the clearest

${ }^{134}$ Hetherington, Marc J., and Elizabeth Suhay. “Authoritarianism, Threat, and Americans' Support for the War on Terror." American Journal of Political Science 55, no. 3 (2011): 546-60. Accessed June 22, 2020. www.jstor.org/stable/23024936. (emphasis mine)

${ }^{135}$ Interview on file with author. 
terms, "We will have so much winning if I get elected, that you may get bored with winning." 136 In a nutshell, then, authoritarianism and SDO are triggered by a perceived threat and people respond by protecting the in-group and excluding the threatening outsider. Lewis calls it "activated vulnerability."

\section{Impact on Religious Minorities: Opposition to Muslims'Rights}

The conflation of the threatening Left with Muslims extends beyond just rhetorical posturing. The political divides are exacerbated regularly by professional fearmongers who develop far-fetched conspiracy theories and the influential figures in media and politics who disseminate the theories. Altogether, these efforts result in significant legal challenges to Muslims' religious rights, from building mosques to anti-bullying programs in public schools.

Many of the conspiracy theories originate at the Center for Security Policy(CSP). CSP-funded author Jim Simpson authored two books on the subject: The Red-Green Axis: Refugees, Immigration and the Agenda to Erase America (2015) and The Red-Green Axis 2.0: An Existential Threat to America and the World (2019). The "Red" points to the red in the communist hammer and sickle emblem, and implicitly connects the political Left, communism, and socialism. The "Green" points to the green often found in the national flags of majority-Muslim countries; green symbolizes Islam. According to Simpson, this axis of Islam and liberalism endeavors to re-create America and fundamentally alter its culture - a process he calls"civilization jihad."

CSP-funded writer MatthewVadum discusses a similar theme in Team Jihad: How Sharia-Supremacists Collaborate with Leftists to Destroy the United States (2017). Meanwhile, David Horowitz, well-known for his anti-Muslim advocacy, wrote UnholyAlliance: Radical Islam and the American Left back in 2006. In addition, Andrew McCarthy, a former Assistant US attorney and

\footnotetext{
${ }^{136}$ Kaufman, Scott Eric. 2015. "Donald Trump: If elected, 'we'll have so much winning, you'll get bored with winning." Salon, September 9, 2015. https://www.salon.com/2015/09/09/donald_trump_if_elected_well_have_so_much_winning_youll_get_bored_with_winning/
} 
a columnist for the National Review, proposes a similar theory in The Grand Jihad: How Islam and the Left SabotageAmerica (2010).

In all cases, the idea is that the politicalLeft in the US is working with Muslims to destroy America's Christian character. The fearmongers reason from this that any attempt by liberals to expand protections or rights for Muslims must be resisted as part of a broader effort to preserve the US as a Christian nation. Among other things, this impulse has resulted in a nationwide resistance movement to mosque-building. Guided by CSP's handbook, "Mosques in America: A Guide to Accountable Permit Hearings and Continuing CitizenOversight," 137 Americans have learned to "express questions and reservations in a manner appropriate to the relevant civic forum's purpose" and avoid "expressing alarm as hysteria" as that could be "used to characterize the entire oversight effort as racially biased and ignorant." The efforts have borne many successes; today, mosque construction is almost always challenged and often delayed by years due to these protests.

In the public school context, Christian advocacy groups like the Freedom of Conscience DefenseFund (FCDF) and American Center for Law and Justice (ACLJ) regularly challenge accommodations for Muslim students in public schools. FCDF has successfully contested a Washington state school district that sought to provide a welcoming environment for Muslim students fasting during Ramadan. FCDF is also currently planning to oppose an anti-bullying program in Minneapolis which was created in response to complaints about faith-based bullying filed by the city's large Somali-Musli population. ${ }^{138}$ Furthermore, it is investigating a program in Seattle public schools that seeks to better inform students about Islam and its holidays as well as create a safer

\footnotetext{
${ }^{137}$ Lugo, Karen. 2016. Mosques in America: A Guide to Accountable Permit Hearings and Continuing Citizen Oversight. Washington, DC: Center for Security Policy Press. http://www.centerforsecuritypolicy.org/wp-content/uploads/2016/12/Mosque_in_America.pdf

138 FCDF. 2018. "FCDF Demands Emails from Minneapolis Public Schools Regarding Relationship with CAIR.” August 17, 2018. https://www.fcdflegal.org/fcdf-demands-emailsfrom-minneapolis-public-schools-regarding-relationship-with-cair/
} 
and more accepting atmosphere for Muslim students. ${ }^{139}$

Meanwhile, with ACLJ's help, parents and students have protested against school lessons on Islam, which is taught in cultural and historical terms alongside other religions in various social studies courses. In a Georgia case, parents balked at a worksheet that tested students on various Muslim beliefs. They objected in particular to the fill-in- the- blank sentence: "Allah is the [blank] worshipped by Jews \& Christians," the correct answer being "same God." 140 In Maryland, a student challenged another fill-in-the-blank sentence about the Islamic creed. Students had to answer that, according to Islam, "There is no god but Allah and Muhammad is the messenger of Allah." After the complaining student lost her case in the appellate court, she took it to the US Supreme Court, which turned it down in October 2019. ${ }^{141}$ In New Jersey, the same fill-in-the-blank sentence, given as homework after students watched a brief cartoon video on the five pillars of Islam, ignited complaints that landed the parents on Fox's "Tucker Carlson Tonight." The discussion there alleged that the school district "was suppressing discussion about Christianity while proselytizing Islam." 142 In other cases, oppositions like this have resulted in everything from textbooks being rewritten to schools being placed in emergency lockdowns due to threats.

\section{Conclusion}

139 FCDF. 2018. "FCDF Sends Letter to Seattle Public Schools Regarding Pro-Muslim Program.” July 8, 2018. https://www.fcdflegal.org/fcdf-sends-letter-to-seattle-publicschools-regarding-pro-muslim-program/

140 Tagami, Ty. 2015. "Lessons about religion stir, and are stirred by, suspicion of Islam." The Atlanta Journal-Constitution, October 5, 2015. https://www.ajc.com/news/local-education/lessons-about-religion-stir-and-are-stirredsuspicion-islam/w6nfM7CMxchh1fOantyGZO/

${ }^{141}$ Bloomberg Law. 2019. "Islam in Public School Challenge Rejected by Supreme Court." October 15, 2019. https://news.bloomberglaw.com/us-law-week/islam-in-public-schoolchallenge-rejected-by-supreme-court

${ }^{142}$ Katz, Matt. 2017. "Allegations of Islam Indoctrination in Public Schools Spread to New Jersey." WNYC, April 10, 2017. https://www.wnyc.org/story/allegations-islam-indoctrinationpublic-schools-spread-nj/ 
America is increasingly becoming consumed with political tribalism. Our political identities have morphed well beyond issue positions to include racial, religious, and other traits, such that an electoral loss for our team exerts tremendous psychological pressure on us. This polarization, coupled with perceptions of threat that heighten social-psychological tendencies toward social dominance and authoritarianism, results in concrete harm to religious(and other) minorities. That is, tribalism sets up the dynamic that transforms members of the out-group from fellow humans who are entitled to human rights to members of an out-group who must be defeated at all cost, lest our own team "loses."

This phenomenon is evident in the treatment of Muslims' rights in the US. Not only is anti-Muslim discrimination minimized by this focus on Christians' own sense of victimhood, it also manifests in active social, political, and legal challenges to Muslims' religious rights. 


\title{
6
}

\section{The Weaponization of Digital Media in the Service of Authoritarianism}

\author{
Olga Gerasimenko \\ Department of Political Science\& International Relations \\ University of Delaware
}

Ever since the Arab Spring, the democratizing and liberating effects of digital and social media have been in the spotlight of academics and journalists. The Internet and new media brought along a "fundamental structural change," one that Carl Builder, a military affairs analyst, predicted would shift the balance of power away from states and in favor of individuals and civil society. ${ }^{143}$ The transformative power of information and activism enhanced by the new technologies raised hopes of democratization in many nations. As social and digital media became essential to the functioning of civil society, political campaigns, and international relations, Larry Diamond and Marc Plattner (2012) claimed that the new practice of information exchange blurred

${ }^{143}$ Carl H. Builder, "Is It a Transition or a Revolution?," Futures 25, no. 2(1993):155-57, https://doi.org/10.1016/0016-3287(93)90161-L. 
borders between information and action. ${ }^{144}$ New technologies, they argued, demonstrated potential to "liberate societies from autocracy." 145

Naturally, governments have been learning and attempting to adapt to technological changes throughout history. An authoritarian state, which has a variety of instruments of coercion, surveillance, and control at its disposal, can retaliate by curbing the flows of information through censorship of content and persecution of the opposition. China is a striking example of one such regime. As one of the most censored countries, it does not allow access to such websites as Google, YouTube, Facebook, Wikipedia, as well as major Western media websites, including The New York Times, CNN, and BBC as of 2021. Rebecca MacKinnon (2012) coined the term "networked authoritarianism" to describe the way Beijing has dealt with the democratizing effect of digital communications and internet-based information flows.

Once authoritarian regimes recover from the initial shock of the new power of civil society to mobilize, organize, and protest, they start to invest in not just countering the new advantage but also reasserting their authority and control. Governments possess considerably more resources than the civil society. Judicious and strategic allocation of resources in technology and capacity building of state security institutions enables governments to get ahead in the new media game. Now we see authoritarian governments use the same new media to manufacture consent, shape public opinion, and legitimize their policies.

Some of the resources helpful for spreading disinformation and propaganda are readily available to any interested entity. For example, Facebook algorithms created for advertisement purposes can be used by government surveillance and control. The tools that put users into categories based on personal and political characteristics in specific geographic areas are publicly accessible and within reach of foreign intelligence agencies and law

${ }^{144}$ Larry Jay. Diamond and Marc F. Plattner, Liberation Technology: Social Media and the Struggle for Democracy,A Journal of Democracy Book (Baltimore, Md.: Johns Hopkins University Press, 2012), x, http://jhupbooks.press.jhu.edu/ecom/ MasterServlet/GetItemDetailsHandler? $\mathrm{iN}=9781421405674 \& q$ ty=1\&source=2\&vi ewMode=3\&loggedIN=false\&JavaScript=y.

${ }^{145}$ Diamond and Plattner, xi. 
enforcement. Facebook has been actively used in political campaigns in nondemocratic states. For instance, Facebook became a vessel for spreading aggression and false information during the Philippine President Duterte's election campaign in 2016. After the election, Duterte used Facebook to target and jail opponents and journalists. ${ }^{146}$

Similar cases are available in the democratic world as well. Spreading disinformation was a major strategy of the Trump campaigns. The campaigns also utilized Facebook to disseminate micro-targeted ads designed to sow confusion and delegitimize anyone criticizing Trump. ${ }^{147}$ The ubiquity of such methods illustrates the reality of the rise of online (or digital) authoritarianism, a phenomenon described in the Freedom House project titled, Freedom on the Net, which reported continuous decline of Internet freedom in the US and across the world. The 2019 report also outlined the use of media platforms as "instruments for political distortion and societal control." 148

The loss of reelection by Trump may suggest that the scale or intensity of his campaign's disinformation operation was not sufficient to ensure victory for him. However, it would be fairer to attribute this outcome to the work of the independent media organizations as well as the strength of the US democratic institutions. The countries that have neither of the two see different political developments. China and Russia are two obvious examples of authoritarian states that seek to challenge US dominance in the world arena and are heavily investing in the new media to achieve that goal.

China, ruled by the Communist Party, is the world's second-largest

146 Lauren Etter, "What Happens When the Government Uses Facebook as a Weapon?," Bloomberg.Com, December 7, 2017, https:/www.bloomberg.com/news/features/2017- 1207/how-rodrigo-duterte- turned- facebook-into-a-weapon-with-a-little-help-fromfacebook.

${ }^{147}$ McKay Coppins, "The Billion-Dollar Disinformation Campaign to Reelect thePresident," The Atlantic, February10, 2020, https:/www.theatlantic.com/magazine /archive/2020/03/the2020-disinformation- war/605530/.

148 Adrian Shahbaz and Allie Funk, "Freedom on the Net 2019: The Crisis of Social Media" (Freedom House, 2019), https:/www.freedomonthenet.org/report/freedom-on-thenet/2019/the- crisis-of-social-media. 
economy and a rising global power. Russia has been under the Putin regime for over twenty years. Both are nuclear powers and permanent members of the United Nations Security Council. China is the world's largest state by population whereas Russia is the biggest in size. Both Russia and China spend a considerable portion of their budgets on control of the media, but their methods and ability to reach global audiences vary.

\section{China and the Control of Information and Media}

China's foreign policy strategy and budget have long included "media warfare." After the 2008 Summer Olympics in Beijing, the government allocated 6.6 billion dollars for global media expansion. China has been heavily investing in foreign-language media, ${ }^{149}$ as well as spending tens of millions of dollars solely on influencing the US. ${ }^{150}$ In pursuit of a "new world media order," in addition to global disinformation campaigns conducted through the social media and messaging apps such as WeChat, China organized and fully funded international media summits as well as foreign journalists' trips and training in China with the purpose of securing favorable coverage; it also financed pro-China ads in the Western media and made content-sharing deals with credible media organizations in order to push for pro-China coverage. ${ }^{151}$

In terms of freedom of expression, China was rated as the fifth most censored country by the Committee to Protect Journalists in 2019 and is one

\footnotetext{
149 "China Is Spending Billions on Its Foreign-Language Media," The Economist, June 14, 2018, https:/www.economist.com/china/2018/06/14/china-is-spending-billions-on-itsforeign- language-media; "China Profile,” BBC News, March 6, 2018, sec.Asia, https:// www.bbc.com/news/world-asia-pacific-13017881.

${ }^{150}$ Louisa Lim and Julia Bergin, "Inside China'sAudacious Global Propaganda Campaign,” The Guardian, December 7, 2018, sec. News, https:/www.theguardian.com/news/20 18/dec/07/china-plan-for-global-media-dominance-propaganda-xi-jinping.

151 "RSF Report: 'China's Pursuit of a NewWorld Media Order' | Reporters without Borders,” RSF, March 22, 2019, https://rsf.org/en/reports/rsf-report- chinas-pursuit-new-world-mediaorder.
} 
of the world's top jailers of journalists. ${ }^{152}$ The Cyberspace Administration of China, founded in 2014, controls which content is allowed on the Internet in China and tracks down violators who face consequences and prosecution. Internet censorship is considered a top priority by the Chinese government. The government dictates the way information is framed, while the press does not have any proper legal protection and the courts are controlled by the government. The authorities oversee the means of production and set the rules for Internet service providers. ${ }^{153}$ China's low press freedom rankings and total control over journalists did not prevent the government from calling the country a "true democracy and a champion of human rights" in a white paper published on the 70th anniversary of thePeople's Republic of China (PRC). ${ }^{154}$ Such statements are an example of a blatant propaganda approach by the Chinese government, possible due to complete lack of accountability. For the last twenty years, virtually all online news in China comes from one source - the Xinhua News Agency, which has been the Party's mouthpiece since before the establishment of the PRC itself. ${ }^{155}$ People's Daily is the largest newspaper in the country and is affiliated with the Party. The online version of the newspaper claims to reach 258 million people per day in over 200 countries. ${ }^{156}$ As most of the alternative sources of information in China are banned, the official media play the main role in presenting any news to the people. For instance, the mostly peaceful 2019-2020 Hong Kong protests

152 "10 Most Censored Countries," Committee to Protect Journalists, September 10, 2019, https://cpj.org/reports/2019/09/10-most-censored-eritrea-north-korea- turkmenistanjournalist.php.

153 "China Profile. Freedom of the Press 2017," Freedom House, April 18, 2017, https://freedomhouse.org/report/freedom-press/2017/china.

154 "For Its 70th Anniversary, the ChineseRegime Masquerades as a Champion of Human Rights | Reporters without Borders," RSF, September 26, 2019, https://rsf.org/en/news/its-70thanniversary-chinese-regime- masquerades-champion-human-rights.

${ }^{155}$ Qinglian He, The Fog of Censorship:Media Control in China (New York: Human Rights in China, 2008).

156 “Introduction to People's Daily,"People's Daily Online, accessedJanuary28, 2020, http://en.people.cn/90827/90828/ 
were portrayed as violent by the state media, which also blamed them on "foreign hostile forces" such as the US. ${ }^{157}$ Similarly, the Chinese newspapers preferred to downplay the severity of the spread of COVID-19 in China during early 2020 and strived to shift the focus elsewhere. ${ }^{158}$ In the absence of alternate sources, such portrayals alone shape public opinion about these events and the government faces no challenge to its worldview or to the policies it adopted to address both the protests and the pandemic. It is safe to say that the main and only purpose of online media in China is to shape public opinion and assist in preserving the regime. The government views controlling the online conversation as essential for remaining in power. The chief editor of People's Daily defined anything less than full control over the media as a potential "historic mistake." 159 While the state-controlled media in China are highly influential domestically due to lack of competition and alternate perspectives, they are less successful at the international level because of the problematic image of China. This does not stop China from attempting to boost its social media presence and create at least an appearance of popularity on Twitter and Facebook, which are blocked in China. The number of followers of

People's Daily English- language Facebook and Twitter pages are rapidly growing, even though there is lack of evidence that the followers' accounts are real. In addition to boosting an image of growth, artificial accounts and bot

${ }^{157}$ Kecheng Fang, "Analysis | What Is China's Propaganda Machine Saying about the Hong Kong Protests?," Washington Post, August 19, 2019, https://www.washingtonpost.com/politi cs/2019/08/19/what-is-chinas- propaganda-machine-saying-about- hong-kong-protests/.

158 Michael Standaert, "Chinese State Media Downplays Coronavirus as Xi Strikes Positive Tone," The Guardian, January 24, 2020, sec. World news, https:// www.theguardian.com/world/2020/jan/24/chinese-state-media- downplays-coronavirusas-xi-strikes- positive-tone.

${ }^{159}$ Eva Dou and Josh Chin, "People's Daily Chief Warns of 'Historic Mistake' If China Loses Grip on New Media,"WSJ (blog), March 21, 2016, https://blogs.wsj.com/chinarealtime/20 16/03/21/peoples-daily-chief-warns-of- historic-mistake-if-china-loses-grip-onnew-media/. 
activity may help generate visibility and cause content to become trending. ${ }^{160}$

\section{Russia and the Weaponization of Media}

In contrast to China, Russia invests considerably more in the quality of propaganda and disinformation campaigns. Russia has a long history of censorship and propaganda. After coming to power, Putin made media control one of the regime's priorities.

Unlike China, Russia's methods do not entail creating an information vacuum for the population. Rather, Russia is focusing on developing its own informational dimension, which would shape and dominate Russians' worldview without severely limiting their access to the rest of the Internet (although Russia does ban some websites and interferes with the work of Western social media websites). The domestic successes of Russia's propaganda machine, which helped preserve Putin's high ratings despite a poor social and economic situation in the country, emboldened the regime to grow increasingly ambitious about shaping the views of people and entities outside of Russia and the Russian-speaking world.

While the 1990s were the freest period for the Russian press, by mid-2000s the state had garnered control over $70 \%$ of the electronic media. The government took freedom and independence away from the media organizations with the help of a host of financial and administrative measures, such as fines and sanctions, legal action against media organizations and individual journalists on the basis of alleged libel, non-compliance with safety regulations, together with banning the undesirable media representatives from accessing information and public events. Additionally, in continuation of the Soviet legacy, self-censorship and violence against journalists persisted and then was taken to a new level. ${ }^{161}$ The political discourse in Russia

${ }^{160}$ Christian Shepherd, "Twitter Tally at People's Daily Does Not Add up, Say Researchers," Financial Times, November 23, 2015, https://www.ft.com/content/43319c90-919a-11e5bd82- c1fb87bef7af.

${ }^{161}$ Anna Arutunyan, The Media in Russia(Maidenhead, Berkshire, England; New York: Open University Press, 2009). 
deteriorated and became permeated with Putin's own cynical vision of reality and interpretation of events. ${ }^{162}$ The discourse was largely built around promoting Russia's new "national idea,"163 which laid the groundwork for the anti-Western rhetoric and elevation of Russia's projected unique experience and moral standing. In order to achieve these goals, Putin's regime made full use of the new technologies. The media budget in Russia is significant: in recent years Russia has been spending over a billion dollars per year on mass media, increasing it to 1.25 billion dollars in 2020. ${ }^{164}$ Russia's state-controlled media are considered "strategic national priorities" and are protected by the government. ${ }^{165}$

One of the media that enjoys generous funding and operates globally is RT, the organization that started as a television channel, "Russia Today," in 2005 and has grown into an influential digital media outlet that reaches out to

\footnotetext{
${ }^{162}$ Natalia Roudakova, Losing Pravda:Ethics and the Press in Post-Truth Russia, 2017. :168- 195

163 The Putin's "Russian Idea" was reflected in his 1999 Millennium Message. Hill and Clifford (2015) asserted that the problem with the Message was that it illuminated the national goals but did not outline the methods of their achievement. By using "emotion and... historic and cultural symbolism," Putin promised to "rebuild the Russian state, protect Russia's sovereignty, preserve domestic stability and unity, and ensure national security," but never mentioned how he would go about it (Fiona Hill, Clifford G Gaddy, and Brookings Institution, Mr. Putin: Operative in the Kremlin, 2015, http://public.eblib.com/choice/ publicfullrecord.aspx? $\mathrm{p}=4321748$.).
}

164 Финансирование СМИ из бюджетапредложено увеличить на треть [Statemedia budget proposed increase by a third]," Interfax.ru, September 26, 2019, https:// www.interfax.ru/russia/678102.; ФаридаРустамова [FaridaRustamova], "Бюджет государственных СМИ в России вырастет на 2,5 млрд рублей [Russia'sstate media budget to increase by 2.5 bnrubles]," ВВС News Русская служба [ВВС News in Russian], May 26, 2017, sec. Новости, https://www.bbc.com/russian/news- 40062877; Gabrielle Tetrault-Farber, "Looking West, Russia Beefs Up Spending on Global Media Giants," The Moscow Times, September 23, 2014, https:/www.themoscowtimes.com/2014/09/23/looking-west- russiabeefs-up-spending-on-global-media-giants- a39708.

165 "Foreign Policy Concept of the Russian Federation (Approved by President of the Russian Federation Vladimir Putin on November 30, 2016)," The Ministry of Foreign Affairs of the Russian Federation, December 1, 2016, https:/www.mid.ru/foreign_policy/official_documents//asset_publisher/CptICkB6BZ29/content/id/2542248p_p_id=101_INSTANCE_CptICkB6BZ29\&_101 
hundreds of millions of people across the world and offers coverage in several languages. RT's reputation as the government's mouthpiece and "the Russian government's main weapon in an intensifying information war with the West" has raised concerns among experts. ${ }^{166} \mathrm{RT}$ is summoned to broadcast Russia's vision of the global affairs and offer "alternative perspectives." 167 The term "information war" is actively used in the Russian media space, which provides further evidence that information, or disinformation, is purposefully weaponized and employed to serve the regime. The Russian media use a variety of tactics, including elaborate story-telling, delegitimization and subtle negative coverage, along with manipulation of vague but emotionally appealing concepts such as morality. Whether the goal is to cause confusion or distraction, suppress voters, or to manipulate public opinion or political elites' views, both the official media like RT and the covert operations performed by troll factories represent a sizeable and dangerous opponent of the democratic forces and structures in the world as they strive to dominate the global discourse and succeed in its disruption.

Russian propaganda and disinformation campaigns that fuel its information war against the West are the centerpiece of Russia's so-called hybrid warfare ("Hydra") - a range of methods used by the government to promote its agenda in international affairs. These techniques also include conventional warfare, private military companies, intelligence and espionage, economic tools, diplomacy, lawfare, and cyberwarfare. ${ }^{168}$

The Russian regime can be pursuing a number of goals by using a combination of strategies. The lack of military strength and weakening resource-based economy, which is under sanctions, are compensated by cyberattacks that can both destabilize the target and yield intelligence results.

\footnotetext{
${ }^{166}$ Simon Shuster, “Inside Putin's Media Machine,” TIME.Com, March 5, 2015, http://time.com/ rt-putin/.

167 “About RT,” RT International, accessed December 13, 2018,https:/www.rt.com/about-us/.

168 Georgi Beltadze, "Mark Voyger: Russian Hybrid Warfare Can Still BringSurprises in the Future," Estonian news news.postimees.ee, June 18, 2018, https://news.postimees.ee/4505726/mark-voyger-russian-hybrid-warfare-can- still-bring- surprises-in-thefuture.
} 
Lawfare refers to the way Russia manipulates the international law and creates justifications for military intervention - as happened in Ukraine and Georgia. Specifically, the regime justified the intervention in both cases by the need to protect ethnic Russians living there. As a part of Russia's involvement in the war in Ukraine, Russia held a referendum in Crimea, which was deemed illegal by most countries, in order to justify the annexation of the peninsula. Additionally, using hybrid warfare allows Russia to achieve certain objectives in a more clandestine way without an open confrontation. ${ }^{169}$

The information warfare is critical for each of the branches of the "Hydra." The propaganda machine works to manufacture consent for a war from the Russian population and continued support of the regime, which includes "patriotic education." The internationally-oriented propaganda strives to find support among the foreign governments, elites, and people in general, while simultaneously attempting to undermine leadership of the West and liberal values.

Russian hybrid warfare came into play during the interference in the 2016 US presidential election. In an attempt to help Donald Trump win the election, hackers sponsored by the Russian government conducted cyberattacks against the Democratic National Committee and targeted voterregistration systems. Russia also provided financial assistance by funneling illegal money through the National Rifle Association. In addition, Kremlinemployed and managed Internet trolls and bots launched social mediabased campaigns aimed at suppressing voters and sowing discord in the US society. The campaign conducted by Russia's so-called troll factory succeeded in reaching millions of Americans and engaging them in various ways. ${ }^{170}$

\footnotetext{
${ }^{169}$ Mason Clark. Institute for the Study of War, "Russian Hybrid Warfare," September 2020, http://www.understandingwar.org/ report/russian-hybrid-warfare; http://www.understandingwar.org/ sites/default/files/Russian\%20Hybrid\%20Warfare\%20ISW\%20Report\%202020.pdf.

170 “The Mueller Report, Annotated," Washington Post, July 23, 2019, https:// www.washingtonpost.com/graphics/2019/politics/read-the-muellerreport/; "Highlights From The Mueller Report, Annotated," NPR.org, April 18, 2019,https:// www.npr.org/2019/04/18/708965026/highlights-from-the-mueller-report.
} 
The US Senate Intelligence Committee confirmed "extensive activity" by Russia to meddle with the election and called for the US to strengthen its defense capabilities. ${ }^{171}$ In the months prior to the 2020 election the US intelligence warned about "a range of measures" used by Russia to intrude once again. ${ }^{172}$ It was subsequently reported that the interference was significantly less successful this time, for a few possible reasons, including the strengthened US infrastructure, decreased motivation by Russia, and the fact that PresidentTrump himself became the largest source of disinformation during the election season. ${ }^{173}$

\section{Conclusion}

The development and wide use of new media raised hopes for a more democratic future of the world. The scholars and journalists underscored the democratizing effects of the new media and technologies, which they predicted could liberate societies and dismantle autocratic regimes. Today's realities, however, demonstrate that many authoritarian states largely succeeded in adapting to the situation and learned to utilize the new media to their own advantage. The authoritarian governments, like those of Russia

171 The Select Committee on Intelligence, United States Senate, "Report on Russian Active Measures Campaigns and Interference in the 2016 U.S. Election. Volume 1: Russian EffortsAgainst Election Infrastructure with Additional Views" (Washington D.C.:U.S. Senate, July 2019), https://www.documentcloud.org/documents/6214293-Report-Volume1.html.

172 "Statement by NCSC Director WilliamEvanina: Election Threat Update for the American Public,"Office of the Directorof National Intelligence, August 7, 2020, https://www.dni.gov/index.php/newsroom/press-releases/item/2139- statement-by- ncscdirector-william- evanina-election-threat-update-for-the- american-public.

${ }^{173}$ Ellen Nakashima, "Fewer Opportunities and a Changed Political Environment in the U.S. May Have CurbedMoscow's Election Interference This Year, Analysts Say," Washington Post, November 17, 2020, https:/www.washingtonpost.com/nationalsecurity/russia-failed-to- mount-major-election-interference-operations-in-2020-analystssay/2020/11/16/72c62b0c-1880-11eb-82db-60b15c874105_story.html; Julia Carrie Wong, "Putin Could Only Dream of It': How Trump Became the Biggest Source of Disinformation in 2020," TheGuardian, November 2, 2020, sec. US news, https:/www.theguardian.com/usnews/2020/nov/02/trump-us-election- disinformation-russia. 
and China, strive to acquire new technologies and heavily invest in new media, enabling them to assert their power and maintain control. Even if it takes a government longer to learn and adapt than it takes civil society, the resources that a government possesses and is willing to spend on boosting its authoritarianism can be vast. Both the Russian and the Chinese regimes have sent clear signals that their ultimate goal is the monopoly on information at the domestic level and domination at the international level. The West should take this information war seriously. 


\title{
Annotated Bibliography
}

\author{
Fahmida Zaman and Sumeyra Yildirim \\ Department of Political Science \& International Relations \\ University of Delaware
}

Adetula, V. AO. (2011).Measuring democracy and good governance in Africa: A critique of assumption and methods. Kwandiwe Kondlo, Chinenyengozi Ejiogu (eds). Africa in focus: Governance in the 21st century. Human Science Research Council.

In this chapter, the author discusses the limits of liberal democracy along with the assumptions and methods that have been used to measure democracy and good governance in Africa by international donors and scholars. The author argues that many of the findings and conclusions in the donorfunded assessment reports on democracy and good governance in Africa are concerned essentially with regime type rather than the nature of the state and its relationship to the processes and outcomes of democratization. The article also highlights that most of the reports on the topic produced by international donors ignore the structural contradictions as a multifaceted constraint that prevents the actualization of democracy in Africa.

Bardhan, P. (2002). Decentralization of Governance and Development. Journal of Economic Perspectives, 16 (4), 185-205. https://- 


\section{doi.org/10.1257/089533002320951037}

In the economic policies of countries such as China and India as well as small countries in Latin America, Africa, and Asia, decentralization had been at the center stage. Decentralized governments were credited for industrial growth so much so that the World Bank and others embraced it as one of the major governance reform agendas. However, Pravab Bardhan argues that the literature on decentralization needs to go beyond the fiscal federalism literature. This is because the institutional context, hence the structure of incentives and organization, in developing and transition economies are quite different from the institutional context of industrial economies. For decentralization to work in developing and transition economies, there needs to be significant change in the existing structures of power within communities and to improve opportunities for participation of the disenfranchised in the political process.

\section{Bellin, E. (2004). The robustness of authoritarianism in the Middle East: Exceptionalism in comparative perspective. Comparative Politics, 139-157.}

Why have the Middle East and North Africa remained so singularly resistant to democratization? In answering this question, some argue that the Middle East and NorthAfrica lack the prerequisites of democratization - the lack of a strong civil society, a market-driven economy, adequate income and literacy levels, democratic neighbors, and democratic culture explains the region's failure to democratize. Bellin contrasts these propositions and argues that the Middle Eastern exceptionalism does not lie in the absence of prerequisites of democracy. Rather, what distinguishes this region from others with regards to democratization efforts are a) access to abundant rent and subsidies that cover much of the cost of these overdeveloped coercive apparatuses and $b$ ) multiple western security concerns in the region guaranteeing continuous international support to authoritarian regimes in the Middle East and North Africa even after the cold war. These factors reinforce the coercive apparatus' capacity and prevent democratic reform. 
Besley, T. (2006). Principled agents?: The political economy of good government. Oxford University Press.

What is the role of government in the economy? One set of scholars argue that government is the force for public good that should regulate market, distribute resources, and should work towards improving the lives of its citizens. Another set of scholars argue that government is an agent-driven by private interest, susceptible to those with the power to influence its decisions and failing to incentivize its officials to act for the greater public good. In this book, the author utilizes the Publius approach that acknowledges a middle ground. Timothy Besley discusses the institutional preconditions of effective governance and argues that it is not just about designing an appropriate institutional framework but also about understanding the way incentives work and the process by which the political class is selected.

Bloom, P. (2016). Authoritarian Capitalism in the Age of Globalization. Cheltenham: Edward Elgar Press.

In this book, Peter Bloom explores the rise of authoritarian capitalism in the age of globalization. He questions the possibility of breaking free from the results of authoritarian capitalism in the twenty-first century. Bloom argues that political authoritarianism is replacing liberal and social democracy. $\mathrm{He}$ points out capitalism's disciplining power through authoritarian nationalism, marketization, authoritarian modernization, authoritarian freedom, and authoritarian good governance. He challenges the conventional argument that capitalist prosperity can only be achieved through promotion of democracy by addressing the interplay between political authoritarianism and capitalism. He defines this process as "the tyranny of neoliberal democracy." This is a very engaging critical inquiry in grasping the structural factors beyond authoritarian tendencies around the globe.

\section{Brownlee, J. (2007). Authoritarianism in an Age of Democratization. Cambridge University Press.}

The academic literature inspired by the extraordinary enthusiasm for the third wave of democracy ignored the evidence that many authoritarian 
regimes remained in power. Addressing this puzzle of varying fates of authoritarian regimes in the third wave period, Jason Brownleein his book asked why are some autocratic governments overthrown after introducing elections, whereas others hold elections yet maintain autocracy? Brownlee argues that institutional differences distinguish unstable authoritarian regimes from durable dictatorships in which the presence and strength of ruling parties is a determining factor. Ruling parties can offer the structure for collective agenda-setting and dispute mediation that regulate elites'clashing preferences and ambitions. As a result, whether an autocratic regime can survive or fall is determined by the availability of "soft-liners," a section of moderates who can ally with the regime to create mass support. Thus, the emergence of structural opportunities for democratization necessitates the decline of ruling coalitions.

\section{Cooley, A. (2015). Authoritarianism Goes Global: Countering Demo- cratic Norms. Journal of Democracy 26(3).}

This article demonstrates the transformation of authoritarianism and the rising influence of non-Western powers and norms over the past decade. It explains how authoritarians implement the novel apparatus as well as practices, institutions, and alternative values to their advantage against the liberal international order. Cooley argues that global political changes and systemic transformations resulted in alternative norms that challenge liberal democracy and prioritize state security, civilizational diversity, and traditional norms. The author demonstrates these changes via a special emphasis on nongovernmental organizations (NGOs).

\section{de Sales Marques, J. L., \& Meyer, T. (Eds.). (2018). Multiple Modernities and Good Governance (1st ed.). Routledge.}

In this edited volume, José Luís de Sales Marques and Thomas Meyer represent a detailed investigation of the concept of "Multiple Modernities." The book addresses principal concepts such as development, good governance, human security, dialogue, harmony and human dignity, globalization, plural modernity, and varieties of capitalism. Addressing negotiated universals, 
the chapters provide alternative approaches to the concept of "multiple modernities" which enable us to discover the commonalities and differences in different regions around the globe. This book opens up novel ways of understanding and asks bold questions such as: Whose modernity? This book is a must-read to comprehend the possibility of good governance in a world of multiple modernities which is "available to all."

Diamond, L. J., Plattner, M. F., \& Walker, C. (Eds.). (2016). Authoritarianism goes global: The challenge to democracy. Johns Hopkins University Press.

Over the last decade, just as authoritarian countries such as China and Russia have found new ways of authoritarian governance, established democracies such as the United States and India have experienced decline of democratic values and norms. In this period, authoritarianism has gone global because) authoritarian countries have been more assertive and have shared authoritarian tactics and practices with each other and b) in doing so, they have challenged the liberal international political order and standing of liberal democracy. Edited by Larry Diamond, Marc F. Plattner, and Christopher Walker, a distinguished group of scholars come together in Authoritarianism goes global: The challenges to democracy to offer fresh insights on the issues of worldwide democratic decline. Thematically, the book focuses area of "softpower" competition centering on the role of information/disinformation war, civil society, and democratic norms. The collection of essays in this volume advance our understanding of the emerging challenges to democracy by focusing on authoritarian resurgence and implications of the systemic shifts for international order.

Donno, D. (2013).Elections and Democratization in Authoritarian Regimes. American Journal of Political Science, 57(3), 703-716.

In this article, Donno addresses an interesting puzzle - when do elections in authoritarian regimes lead to democracy? The author argues that competitive authoritarian elections have a better chance of resulting in democracy when the incumbent regime is relatively weaker. However, this is contingent upon 
domestic and international pressure - when there is an oppositional electoral coalition that is a unified front and when international actors threaten to punish the regime for violation of electoral norms. Using a comprehensive dataset of elections in authoritarian regimes from 1990s to 2007, Donno confirms these findings and argues that alternative explanations such as the differences across regime type, better electoral conduct, or ongoing process of liberalization are not supported by the evidence.

\section{Doornbos, M. (2001). "Good Governance": The Rise and Decline of a Policy Metaphor? The Journal of Development Studies, 37(6), 93-108.}

Doornbos traces the rise and fall of good governance as a policy metaphor in international aid context. He illustrates that the notion of 'good governance' as a political condition has been a prominent policy requirement for international aid since 1989 onward. As part of a series of interlocking policy criteria and initiatives, international donor agencies enacted good governance on donor-recipient countries. The genealogy of good governance metaphor is that it was first presented as a key objective in donor development and foreign policy in its own right; then, some donors treated it as a selection criterion for aid recipient countries, while more broadly it appears to be evolving into a general figure of speech without too much practical consequence. Thus, Doornbosargues, the "leverage to induce good governance" has not worked out as envisaged because it was posed as political conditionalities and policy metaphor; as such, the good governance connotation has lost its appeal.

Gandhi, J., \& Przeworski, A. (2007). Authoritarian Institutions and the Survival of Autocrats. Comparative Political Studies, 40(11), 1279-1301. https://doi.org/10.1177/0010414007305817

Jennifer Gandhi and Adam Przeworski address the issues of autocratic resilience by asking - why do some autocrats survive for decades, and others fall soon after taking power? Gandhi and Przeworski argue that autocrats face two types of threats to their rule: internal challenges which come from the ruling elite and external threats that come from outsiders within society. In order to tackle internal challenges from within the 
ruling class, authoritarian rulers establish narrow institutions such as consultative councils, juntas, and political bureaus. However, the authors argue that in order to neutralize challenges from outsiders within society, authoritarian rulers utilize "nominally democratic institutions." Particularly, the authoritarian rulers seek support from partisan legislatures to solicit cooperation and to neutralize the threat of rebellion from forces within society thus investing these actors in the ruler's survival. The authors test this hypothesis by analyzing all authoritarian rulers in power from 1946-1996.

\section{Gilbert, L., Mohseni, P. (2011) Beyond Authoritarianism: The Concep- tualization of Hybrid Regimes.St Comp Int Dev 46, 270-297.}

In this article, Leah Gilbert and Payam Mohseniexamine hybrid regimes by portraying the tensions and obscure relationships of democracy and authoritarianism. Their configurative approach challenges the idea of regimes' linear continuum (from authoritarianism to democracy). Instead, they focus on the alternative multi-faceted arrangements viable for the construction of regime types. This examination provides a better understanding of hybrid regimes and their particularities. The article's configuration helps readers to think about hybrid regimes beyond the framework of authoritarianism.

\section{Guriev, S., \& Treisman, D. (2020). The Popularity of Authoritarian} Leaders: A Cross-National Investigation. World Politics, 72(4), 601-638.

This article, investigating the Gallup World Poll's panel of countries in 2006-2016, argues that the factors for political approval of authoritarian leaders vary across different regime types. It focuses on the perceptions of the individuals about their authoritarian states. The authors illustrate the different degrees and styles of authoritarian rule across the globe and try to uncover the reasons for the various levels of approval by their citizens. To that aim, they deepen our understanding of these different levels of approval through a cross-national investigation of elements such as economic performance, public safety, and covert censorship. Comparing overt dictatorships to milder informational autocracies, they conclude that the greater the repression, the lower the chance of approval. 


\section{Hadenius, A., \& Teorell, J. (2007).Pathways from Authoritarianism. Journal of Democracy, 18(1), 143-157.}

On the question of prospects for democratization, some theories such as modernization theory attribute socioeconomic development as the main criteria while others have identified culture and religion, natural resources, and diffusion effects as major factors. Axel Hadenius and Jan Teorellin this article pay attention to the institutional requisites for democracy. They ask whether certain authoritarian regimes are more likely to break down and, if so, are certain types more likely to democratize? Do the institutional attributes of the authoritarian regime affect a country's prospects for democratic transition? To answer these questions, the authors develop a new typology of authoritarian regimes covering 191 countries in the world from 1972 to 2003. They argue that different types of authoritarianism have different propensities for survival and for democratization. Hence an institutional attribute - nature of the authoritarian regime - should be considered in any discussion of democracy's preconditions.

Hadiz, V. (2016). Islamic Populism in Indonesia and the Middle East. Cambridge: CambridgeUniversity Press.

This book compares the evolution of Islamic populism in Indonesia to the Middle East. From a critical materialist approach, Hadiz argues that we cannot grasp Islamic Politics in different geographies without a deeper understanding of power, material resources, and social-historical structures. Through detailed case studies across the Middle East and Southeast Asia, he offers an in-depth analysis of political change in the context of socioeconomic transformations. The case studies also tackle broader theoretical questions and present an innovative, comparative framework to shed new light on the diverse trajectories of Islamic politics in the modern world. $\mathrm{He}$ highlights the importance of the evolution of Islamic doctrines and ideologies in the modern world.

Hagmann, T., \& Reyntjens, F. (Eds.). (2016). Aid and authoritarianism in Africa: Development without democracy. Zed Books. 
This edited volume by Tobias Hagmann and Filip Reyntjensexamines the intersection between the international aid industry and politics from a variety of perspectives with a particular focus on Africa. The contradictory natures of the claims of democracy and human rights promotion by major bilateral and international donors, such as USAID, DFID, the World Bank and the European Commission, are particularly scrutinized as the aid policies in the region has become ever more entangled with the survival of their authoritarian protégés. The book sheds light on the political intricacies and moral dilemmas of development policies which are shaped in the interest of maintaining the status quo. The book encourages research on a) moving beyond donor- speak and opening the "black box" of aid; b) addressing the accountability gap, i.e., the absence of a feedback loop between African citizens and Western taxpayers; c) research on historical trajectories, and d) "autocratic modernities," i.e., the attempts by African political elites to "amalgamate authoritarian politics with (neo-)liberal discourses emphasizing efficiency, effectiveness, and performance."

Hatchard, J., Ndulo, M., \& Slinn, P. (2004). Comparative Constitutionalism and Good Governance in the Commonwealth: An Eastern and Southern African Perspective. Cambridge: Cambridge University Press.

This book explores the constitution-making processes in the Commonwealth countries (Eastern and Southern) and addresses the legal issues in the process of capacity building to ensure good governance. First, the authors draw our attention to the importance of good governance for the economic and social development of a country. Then, through a comparative approach, they aim to find out solutions to the problems of constitutionalism and draw lessons to make legislatures effective. The book features chapters analyzing presidentialism and restraints upon executive power's access to the political system, the devolution of power to local communities, and constitutional control of the military.

Hill, J. (2016). Democratisation in the Maghreb. Edinburgh: Edinburgh University Press. 
Democratisation in the Maghreb is a comparative analysis of democratization processes and political development in Tunisia, Algeria, Morocco, and Mauritania. This book challenges but also extends Levitsky and Way's model for examining political transitions by contextualizing each country's different experiences. After providing a detailed picture of post and pre-Arab Spring landscape, Hill argues that even though all of the countries in the region had been affected, and even though they had shared similar demands under similar conditions, their individual protest movements have resulted in different outcomes. These different outcomes provided by the article may deepen our perspectives about political development, governance, and authoritarianism.

Hooghe, M., \& Quintelier, E. (2014). Political participation in European countries: The effect of authoritarian rule, corruption, lack of good governance and economic downturn. Comparative European Politics, 12(2), 209-232.

Hooghe and Quintelier examine why the political participation levels in Central and Eastern Europe remain significantly lower than in Western European countries. The authors introduce a distinction between institutionalized and non-institutionalized forms of participation by conducting a multilevel analysis on the full sample of the European Social Survey in the period 2002-2008. The analysis of the data suggests that historical legacy of authoritarian regimes in these countries is an insufficient explanatory variable. Instead, high levels of corruption and lack of good governance appear to have a stronger effect on political participation. As a result, democratic participation levels are subjected to levels of corruption, which should be investigated more in-depth.

Ishiyama, J. (2019). Is Democracy Necessary for Good Governance? Social Science Quarterly, 100(6), 2188-2208.

John Ishiyama sheds light on the fact that a natural relationship between democracy and governance is assumed. By conceptually distinguishing democracy from good governance, Ishiyama investigates which regime type is more conducive to good governance. Data from 115 countries from 1996 
to 2011 , he finds that a) there is no difference between one-party regimes and democracies in terms of promotion of rule of law or effective governance in developing countries and b) some types of semi- authoritarian one-party regimes are better at promoting rule of law and effective governance than other types of authoritarian regimes and democracies. Thus, challenging the extant literature, this article demonstrates that democracy does not appear to be necessary for good "enough" governance.

\section{Kendall-Taylor, A., Frantz,E., Wright, J. (2020) The Digital Dictators: How Technology Strengthens Autocracy. Foreign Affairs.}

Authoritarian policies and institutional arrangements have spread across different regions of the globe and the norms about what makes up a legitimate regime has shifted dramatically. Within this framework, this article focuses on the new apparatus of authoritarian regimes: technology. New technologies, including the Internet and the cell phone, are widely perceived as promising which can ease the ways in which individuals create new connections and build communities through information. However, the authors contend that this is not the case. They challenge this view by illustrating how rulers use novel methods for their very survival. According to the authors, artificial intelligence (AI) allows authoritarians to advance techniques of monitoring and tracking of opposition. These digital tools enable authoritarian regimes to control a wider net by using fewer resources. Moreover, they conclude, this digital control is normalized in people's minds so that their resistance capacity to the system diminishes.

Khan, H.A. (2015). The Idea of Good Governance and the Politics of the Global South: An Analysis of Its Effects (1st ed.). Routledge.

In The Idea of Good Governance and the Politics of the Global South, Haroon A. Khan argues that the lack of good governance is the main trait of failed states. Presenting the major objectives of good governance such as human development and bureaucratic capacity, Khan contends that without good governance, many developing countries may become failed states. $\mathrm{He}$ strengthens his argument by the findings from the case study on the garment 
factory tragedy in Bangladesh. In so doing, Khan directs our attention to the importance of bureaucratic capacity for achieving good governance and the effects of globalization. Focusing on good governance and its relationship with failed states, globalization, bureaucratic effectiveness, and human development, this book provides a causal explanation for the relation between good governance and failed states.

\section{Lagerkvist, J. (2009). Chinese eyes on Africa: Authoritarian flexibility versus democratic governance. Journal of Contemporary African Stud- ies, 27(2), 119-134.}

This article asks and attempts to answer two important questions regarding the impact of China's aid to and trade with African states: a) does China's 'no-strings- attached' policy in Africa constitute a challenge to Western aid paradigms and $b$ ) is there an emerging state-sponsored Chinese model of 'effective governance,' guided by a south-south vision of mutuality, equality, and reciprocity at work? The author argues that although there are problems, there is reason to be hopeful about China's relations with African states because China is unwilling to force its experience of 'a market economy with Chinese characteristics' upon other nations. Hence, African analysts argue that local context should determine the development models for their countries and region. However, China's Africa watchers are cautious not to project any false hopes into the bilateral relationship between China and African states.

Lai, H. (2016). China's governance model: flexibility and durability of pragmatic authoritarianism. Routledge.

In China's governance model: flexibility and durability of pragmatic authoritarianism, Hongyi Lai explores how China's political development model can generate an alternative governance model which he defines as "pragmatic authoritarianism." The author underlines "the ability of China's government to rapidly transform a once impoverished economy and to recover from numerous crises from 1978 to the present" and provides an investigation of changes in China's institutions dealing with critical crises 
since 1978. Assessing leadership succession, crisis management, social welfare, leadership succession, and intraparty and grass-roots democracy, he portrays a positive view about the durability of governance in China. He also provides predictions about the future direction of China's governance model.

\section{Leftwich, A. (1993).Governance, Democracy and Development in the Third World. Third World Quarterly, 14(3),605-624.}

The dominant narrative of Western aid policies and development industry assert that 'good governance' and democracy are not simply desirable but essential conditions for development in all societies. This narrative has also recently asserted that democracy is a necessary prior or parallel condition of development, not an outcome of it. This assertation, of course, challenges modernization theories that contend that socio-economic development leads the way to democracy. Beginning in early 1990s, democratic good governance began to emerge not simply as the new technical answer to the difficult problems of development but also as an intimate part of the emerging politics of the New World Order. Leftwich, in 1993, argues that the celebration of a victorious worldwide democratic revolution is hopelessly premature and that an era of democratic reversal, not democratic consolidation, is impending.

\section{Levitsky, S., \& Way, L. A. (2002). Elections Without Democracy: The Rise of Competitive Authoritarianism. Journal of Democracy 13(2), 51-} 65.

In this 2002 article, Steven Levitsky and Lucan A. Way explore the concept of competitive authoritarianism. Challenging conventional thought, they demonstrate the arenas of contestation and the potential for opposition within these non-democratic polities. The authors question the literature on hybrid political regimes and provide an alternative yet robust theoretical framework. They argue that the literature often treats these hybrid regimes as incomplete or transitional forms of democracy. However, the authors challenge this assumption and illustrate how different regimes across the globe have either remained hybrid or moved in an authoritarian direction. Within this framework, they demonstrate how authoritarian regimes utilize 
formal and democratic institutions as means of obtaining and exercising political authority. They also underline the democratizing bias within the literature. In this regard, they argue that one should "stop thinking of these cases in terms of transitions to democracy and to begin thinking about the specific types of regimes they actually are." This detailed examination of competitive authoritarianism contends that "different mixes of authoritarian and democratic features have distinct historical roots, and they may have different implications for economic performance, human rights, and the prospects for democracy."

\section{Levitsky, S., \& Way, L. (2005).International Linkage and Democratiza-} tion.Journal of Democracy, 16(3), 20-34.

Following the end of the Cold War, countries followed different paths with regards to democratization as some countries fully democratized, others became hybrid regimes while some remained autocratic. Levitsky and Way argue that the divergent paths of these regimes were heavily influenced by the countries' relationship to the West-i.e., Western leverage (governments' vulnerability to external pressure) and linkage to the West (the density of a country's ties to the United States, the European Union, and Westernled multilateral institutions). The external democratizing pressure through diffusion, diplomatic or military pressure, multilateral political conditionality, democracy assistance programs, and the activities of transnational human rights and democracy networks, were more intense and sustained in some regions (Central Europe, the Americas) than in others (sub-Saharan Africa, the former Soviet Union). Although both leverage and linkage raised the cost of authoritarianism during the post-Cold War period, it is the linkage that had the stronger effect of democratization.

\section{Lipset, S. M. (1959a).Democracy and Working-Class Authoritarianism. American Sociological Review, 24(4), 482-501.}

In this 1959 article, Lipset argues that the working class, particularly in poorer countries with low level of education, more than other social classes is predisposed to authoritarian and extremist attitudes. This is due to their 
tendency to view politics in "simplistic and chiliastic" way, i.e. black and white, good vs. evil. Thus, other things being equal, working-class population is more likely to be attracted to anti-democratic and extremist movements, many of which suggest easy and quick solutions to social problems.

\section{Lipset, S. M. (1959b). Some Social Requisites of Democracy: Economic Development and Political Legitimacy. American Political Science Re- view,53(1), 69-105.}

In the article, Lipset begins the discussion by identifying methodological and conceptual differences among political philosophers and political sociologists with regards to understanding and studying democracy. In the process, Lipset offers a definition of democracy which has a condition of institutions (i.e., parties, a free press, and so forth) as well as political actors(i.e., ruling and opposition parties). The definition of democracy is followed by discussion of two principal complex characteristics of social systems-economic development (comprising industrialization, wealth, urbanization, and education) and political legitimacy (the degree to which institutions are valued for themselves and considered right and proper). Lipset argues that these are structural characteristics of a society which sustain a democratic political system.

Mawere, M. (2015). Democracy, Good Governance and Development in Africa. LangaaRPCIG.

Scholars and development practitioners tend to view Africa either as a region that is incapable of achieving good governance, democracy, and socio-economic development or are overoptimistic about its potentials. Both of these narratives, however, downplay Africa's diverse as well as complex problems and predicaments. This edited volume engages with numerous issues ranging from the problems, challenges, and prospects of democracy and good governance to possible frameworks for fostering sustainable development in Africa through interdisciplinary engagement. Scholars in this book are gathered from Africa and from different fields of study including social anthropology, philosophy, history, political science, 
education, international relations, culture and heritage studies, religious studies, law, along with media and communication studies. They aim to dissect and critically examine the matrix of Africa's multifaceted problems on governance, democracy, and development in an attempt to proffer enduring solutions to the continent's long-standing political and socio-economic dilemmas and setbacks.

McCarthy, S., \& Thompson, M. R. (2020). Governance and democracy in the Asia-Pacific: Political and civil society. Routledge.

In this edited volume, a distinguished group of scholars come together in exploring the theoretical and empirical relationship between democracy and good governance in the Asia-Pacific region. They advance our understanding through country-specific observations (China, Singapore, Thailand, Cambodia, the Philippines, Myanmar, Fiji, and the Solomon Islands)and through theoretical investigations on the issues of governance, civil society, development, democratic norms, and the rule of law. Providing an in-depth analysis of the structural and current trajectories of polities in the Asia-Pacific, they reveal how the role of civil society, political elites, and governance deviated in different regime structures. This work is important to critically reconsider the good governance literature and locate it in illiberal contexts.

\section{Nanda, V. P. (2006). The "Good Governance" Concept Revisited. The ANNALS of the AmericanAcademy of Political and Social Science,603(1), 269-283.}

Nanda, in this article, traces the different ways the International Monetary Fund, the United States, and the World Bank have defined and used the term 'good governance' as a political condition for their aid policies in Africa. He argues that despite the lack of clarity about the concept, a reiteration of good governance has been helpful in identifying problem areas that hamper the success of development aid. He also argues that the concept can be used effectively only when the cultural context and history are understood and sensitively taken into account. 
Ortmann, S., \& Thompson, M. R. (2020). China's 'Singapore model' and authoritarian learning. Routledge.

In China's 'Singapore model' and authoritarian learning edited by Stephan Ortmann and Mark R. Thompson, the scholars offer a comprehensive historical analysis of the "Singapore Model" and its adaptation in China. This model was used by the CCP to modernize while preserving authoritarian characteristics. This book portrays how Singapore managed economic modernization without having substantial political liberation which challenged the expectations of modernization theory. The authors demonstrate how Singapore became a model of "authoritarian modernism" for China to be implemented in order to bolster the CCP's legitimacy. Offering a detailed analysis of the "Singapore Model" and China's obstacles in internalizing it, they challenge the idea that democracy is the best regime form able to guarantee good governance. They pay special attention to the learning process and knowledge transfer in Chinese reformation through collaboration and bilateral cooperation. However, they argue that the Singapore model is in decline under Xi Jinping. They conclude that there is a loss of interest in the Singapore model "due to Xi Jinping's fundamental reorientation of Chinese policy away from 'calibrated political reforms' and the foreign policy which puts greater emphasis on the success of China's own developmental policies." This book broadens our horizon to reconsider the possibility and importance of alternative epistemic communities and advances our understanding of good governance.

Owen, C. (2020). Participatory authoritarianism: From bureaucratic transformation to civic participation in Russia and China. Review ofInternational Studies, 46(4), 415-434.

In conventional political and policy narratives, it is assumed that authoritarian regimes seek to "disengage and depoliticize" its citizens. In addition, they respond with coercion or co-optation tactics when there is mass mobilization. However, the author argues that such tactics are no longer the go-to mechanism in authoritarian states. Instead, well-established authoritarian regimes, such as Russia and China, have an abundance of 
local, voluntary, participatory mechanisms through which citizens can engage with politics and policy debates. Hence, there is a new form of participatory authoritarianism, and a driving force of such changes has been the marketization of state bureaucracies. This development requires more attention from academics as it challenges the view that authoritarian regimes are exclusively elite-led programs. Instead, it suggests that authoritarian regimes can be deeply embedded at the local level and enjoy grassroots legitimation and support.

Sarsar, S., Datta, R. (2020). Democracy in Crisis Around the World. Lexington Books.

Edited by political scientists Saliba Sarsar and Rekha Datta from MonmouthUniversity, the diverse set of essays in this book address how the rise of authoritarian regimes and populist leaders is threatening democratic values around the world. The chapters point to the emergence of populist leaders and erosion of the core principles of democratic values as well as the capabilities of democratic institutions. The book examines five key regions - sub-Saharan Africa, Eastern Europe, Western Europe, Latin America, and the Middle East and North Africa-as well as four major countries: India, China, Russia, and the U.S. The main argument of the book is that democracies across the globe are in crisis. Highlighting democratic trajectories of different countries, the book aims to uncover the future implications of authoritarian resurgence. Providing the current responses of governments to the COVID-19pandemic, this book sheds light on the fate of democracy for the foreseeable future.

Scheiring, G. (2020) The Retreat of Liberal Democracy: Authoritarian Capitalism and the Accumulative State in Hungary: Challenges to Democracy in the 21st Century. Springer International Publishing

A new wave of autocratization has been at the center stage over the last decade. Hungary's lessons can be relevant across the globe to tackle the inner logic of the worldwide democratic decline. Built upon three years of empirical research, this mixed-methods empirical study is crucial to grasp why liberal 
democracy has retreated. Gabor Scheiring, a Marie Curie Fellow at Bocconi University and a former member of the Hungarian parliament, explores how Hungary's international economic integration resulted in internal socioeconomic disintegration. Scheiring introduces a theoretical framework to better understand the political-economic nature and stability of the post2010 Hungarian regime. According to Scheiring, Hungary's new hybrid authoritarian regime is best understood as a political response to the tensions of globalization. The rising nationalism among the working-class and the negative impacts of deindustrialization translated into the consolidation of illiberal hegemony. The author reveals the political economy of illiberalism in Hungary by explaining the dynamics of the Competition State.

\section{Svolik, M. W. (2012). The politics of authoritarian rule. Cambridge University Press.}

In The Politics of Authoritarian Rule, Milan Svolik asks "What drives politics in dictatorships?" He argues that authoritarian regimes face two fundamental conflicts: (1) Dictators face threats from the masses over whom they rule (the problem of authoritarian control) and (2) challenges dictators face from the elites with whom they rule (the problem of authoritarian power-sharing). Using the tools of game theory, he explains why some dictators, such as Saddam Hussein, establish personal autocracy and stay in power for decades; why leadership changes elsewhere are regular and institutionalized, as in contemporary China; why some dictatorships are ruled by soldiers, as Uganda was under Idi Amin; why many authoritarian regimes, such as PRI-era Mexico, maintain regime- sanctioned political parties, and why a country's authoritarian past casts a long shadow over its prospects for democracy, as the unfolding events of the Arab Spring reveal. The author utilizes statistical analysis of comprehensive, original data on institutions, leaders, and ruling coalitions across all dictatorships from 1946 to 2008.

Thompson, M. R. (2004). Pacific Asia after 'Asian values': Authoritarianism, democracy, and 'good governance.' Third World Quarterly, 25(6), 1079-1095. 
In the aftermath of the 1997 Asian economic crisis, 'Asian values' which was once credited with the region's economic 'miracle' was replaced by globalized 'good governance' discourse. Although there was initial hope of a regional wave of democratization of the region that were swept by development dictators, authoritarian regimes flourished only few years later. In this article, the author makes four arguments: first, Pacific Asia began as an 'imagined community' of developmental dictatorships, which made authoritarian development the 'original position' against which democratic governance is judged; second, the demise of 'Asian values' did not pose a significant challenge to economically developed dictatorships in the region; third, middle class-based reformist movements calling for good governance have contributed to the destabilization of the region's new democracies, and fourth, the U.S.-led anti-terror coalition provided several authoritarian rulers in the region to weaken internal opposition but new democracies faced international pressure to combat terrorism that led to local protest.

\section{Teets, J. C. (2013). Let many civil societies bloom: The rise of consulta- tive authoritarianism in China. The China Quarterly, 213, 19-38.}

Academic literature, as well as democracy promotion project, emphasize that the presence of autonomous civil society organizations is a critical component of the democratization process. The conventional arguments also assume that autonomous civil society opposes authoritarianism. In this article, the author challenges this assumption and demonstrate a new model in which there is collaboration between fairly autonomous civil society and authoritarian regime in China. Naming this model "consultative authoritarianism," Teets argues that the decentralization of public welfare and the linkage of promotion to the delivery of these goods facilitated the local government-civil society collaboration in China. Hence, the "consultative authoritarianism" presents a paradoxical scenario in which there is simultaneous expansion of a fairly autonomous civil society as well as the development of indirect tools of state control. 


\section{8}

\section{Author Biographies}

Dr. Muqtedar Khan is a Professor in the Department of Political Science and International Relations at the University of Delaware. He is a non-resident scholar with IIIT, coordinating the Islam and Good Governance initiative. He was the academic director of the US State Departments' National Security Institute, 2016-2019 and is the academic director of the American Foreign Policy Institute, 2019-2021, at the Institute for Global Studies, UD. He was a Senior Nonresident Fellow of the Brookings Institution (2003-2008) and a Senior Fellow with the Center for Global Policy (2017-2020). He is the author of the award-winning book Islam and Good Governance: Political Philosophy of Ihsan published in April 2019 by Palgrave Macmillan. He is also the author of several other books: American Muslims: Bridging Faith and Freedom (2002), Jihad for Jerusalem: Identity and Strategy in International Relations (2004), Islamic Democratic Discourse (2006), Debating Moderate Islam (University of Utah Press, 2007). His articles and commentaries can be found at www.ijtihad.org. His academic publications can be found at https://udel.academia.edu/MuqtedarKhan. He hosts a Youtube show called Khanversations at: https://www.youtube.com/c/ProfMuqtedarKhan.

Larry Diamond is a senior fellow at the Hoover Institution and at the Freeman Spogli Institute for International Studies (FSI) at Stanford University. He also chairs the Hoover Institution Project on Taiwan in the Indo- 
Pacific Region and is the principal investigator of the Global Digital Policy Incubator, part of Stanford's Cyber Policy Center. For more than six years, he directed FSI's Center on Democracy, Development, and the Rule of Law, where he now leads its Program on Arab Reform and Democracy. During 2017-18, he co-chaired, with Orville Schell, a working group formed of researchers from Hoover and from the Asia Society Center on US-China Relations, culminating in the report China's Influence and American Interests: Promoting Constructing Vigilance (published by the Hoover Institution Press in 2019). He is the founding co-editor of the Journal of Democracy and also serves as senior consultant at the International Forum for Democratic Studies of the National Endowment for Democracy. Diamond is a professor by courtesy of Political Science and Sociology at Stanford University, where he teaches courses on democracy and American foreign policy. He is currently offering Comparative Democratic Development as a massive open online course (MOOC) on the edX platform. Diamond's research focuses on democratic trends and conditions around the world and on policies and reforms to defend and advance democracy. His latest book, Ill Winds: Saving Democracy from Russian Rage, Chinese Ambition, and American Complacency, analyzes the challenges confronting liberal democracy in the United States and around the world at this potential "hinge in history," and offers an agenda for strengthening and defending democracy at home and abroad. (https://profiles.stanford.edu/larry-diamond)

Jessica C. Teets is an Associate Professor in the Political Science Department at Middlebury College, and Associate Editor of the Journal of Chinese Political Science. Her research focuses on governance and policy diffusion in authoritarian regimes, specifically the role of civil society. She is the author of Civil Society Under Authoritarianism: The China Model (Cambridge University Press, 2014) and editor (with William Hurst) of Local Governance Innovation in China: Experimentation, Diffusion, and Defiance (Routledge Contemporary China Series, 2014). Dr. Teets was recently selected to participate in the Public Intellectuals Program created by the National Committee on United States-China Relations (NCUSCR), and is currently 
researching policy experimentation by local governments in China.

Daniel Kinderman holds a Ph.D. (Cornell University, 2011) and joined the Department of Science and International Relations at the University of Delaware in 2011. He is an Associate Professor and Director of European Studies at the University of Delaware. He specializes in comparative and international political economy and corporate social responsibility (CSR), with a geographical focus on Europe. He teaches courses on European politics, the European Union (EU), corporate social responsibility, comparative political economy and international political economy. His current research focuses on business responses to right-wing populism, the impact of responsible business associations on the CSR performance of their member companies and the relationship between CSR and political-economic institutions. Professor Kinderman has been a visiting scholar at the Social Science Research Center (WZB) in Berlin and at the Max Planck Institute for the Study of Societies in Cologne, Germany.

Asma Uddin is the author of When Islam Is Not a Religion: Inside America's Fight for Religious Freedom and the forthcoming The Politics of Vulnerability: How to Heal Muslim-Christian Relations in a Post-Christian America. She is an Inclusive America Project Fellow at the Aspen Institute, where she is leading a project on Muslim-Christian polarization in the U.S. Ms. Uddin was formerly legal counsel at the Becket Fund for Religious Liberty, and has held academic fellowships at Georgetown, UCLA, and Brigham Young University Law School. She is also an expert advisor on religious freedom to the Organization for Security and Cooperation in Europe, and a term- member of the Council on Foreign Relations.

Olga Gerasimenko is a recent Ph.D. graduate of the Department of Political Science and International Relations at the University of Delaware. Her research interests include digital media, authoritarianism, political rhetoric, disinformation campaigns, and cybersecurity. Her dissertation entitled "The War of Words? The Role of New Media in State Propaganda and Foreign 
Policy: The Cases of Russian, Chinese, and Turkish Media News Coverage" focused on explaining how non-democratic states use the state-controlled media to influence international public opinion, generate support for and legitimize their policies and actions, and to shape international discourses on critical issues. Olga also holds an MA (2015) in political science and international relations from the University of Delaware, an MA (2013) in political science from Ohio University, and a specialist degree (2011) from the Far Eastern Federal University (Vladivostok, Russia) in Chinese studies and international relations and foreign policies in East Asia. Olga has taught courses on global politics, politics and the media, and American politics.

Fahmida Zaman is from Bangladesh. She has a BA from the Asian University for Women (AUW) in Bangladesh in Philosophy, Politics, and Economics (PPE) and studied for a year at St. Catherine University in Minnesota as a recipient of the undergraduate fellowship of the US State Departmentfunded Near East and South Asia Study Exchange program. She has an MA from Illinois State University in Political Science. She is one of the co-editors of Political Violence in South Asia, where her chapter focuses on representations of political violence in South Asian English fiction. Her writings on internet freedom, democratization, identity politics, and social movements in Bangladesh have appeared in the Journal of African and Asian Studies, Journal of South Asia as well as in the Daily Star. In the summer of 2020, she was a researcher at the Wilson Center.

Sumeyra Yildirim is a doctoral candidate in the department of political science and international relations at the University of Delaware. She is a Fulbright Scholar. She holds an MA (2012) in political science and international relations from the University of Delaware. Her research interests include Islamophobia, identity, religion, fashion theory, and critical theory. In her dissertation, she seeks to demonstrate the myths linked to Islamophobia and the role of fashion in normalizing and challenging dominant discourses. She worked as a teaching assistant at the department of political science and taught courses at the English Language Institute at the 
University of Delaware. Yildirim has also worked with Institute for Global Studies (IGS) at the University of Delaware, assisting international programs funded by the U.S. Department of State. 


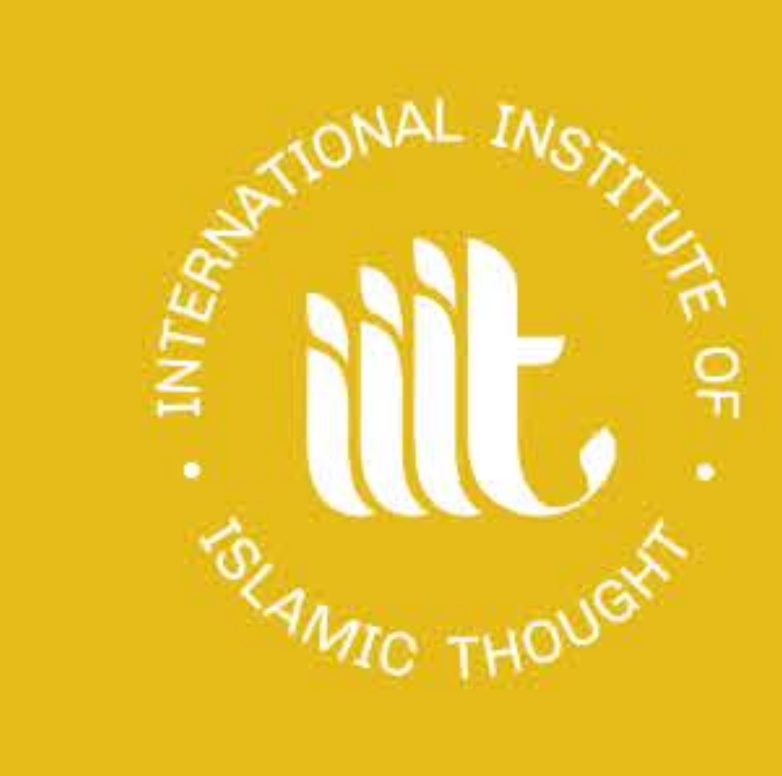

\section{Internatioinal Institute of Islamic Thought (IIIT)}

https://www.facebook.com/IIITriends/

https://twitter.com/iiitfriends

https://www.facebook.com/IIITfriends/

https://www.youtube.com/c/IIITMedia

iiit@iiit.org

www.iiit.org 